\title{
An integrative taxonomic approach reveals Octopus insularis as the dominant species in the Veracruz Reef System (southwestern Gulf of Mexico)
}

\author{
Roberto González-Gómez ${ }^{1,2}$ ， Irene de Los Angeles Barriga-Sosa ${ }^{3}$ ， Ricardo Pliego-Cárdenas ${ }^{4}$ ， Lourdes Jiménez- \\ Badillo $^{2}$, Unai Markaida ${ }^{5}$, César Meiners-Mandujano ${ }^{\text {Corresp., }}{ }^{2}$, Piedad S. Morillo-Velarde ${ }^{6}$ \\ 1 Posgrado en Ecología y Pesquerías, Universidad Veracruzana, Boca del Río, Veracruz, México \\ 2 Instituto de Ciencias Marinas y Pesquerías, Universidad Veracruzana, Boca del Río, Veracruz, México \\ 3 Departamento de Hidrobiología, Universidad Autónoma Metropolitana-Iztapalapa, Ciudad de México, México \\ 4 División de Estudios Profesionales, Facultad de Ciencias, Universidad Nacional Autónoma de México, Ciudad de México, México \\ 5 Laboratorio de Pesquerías Artesanales, El Colegio de la Frontera Sur (CONACyT), Lerma, Campeche, México \\ 6 CONACyT- Instituto de Ciencias Marinas y Pesquerías, Universidad Veracruzana, Boca del Río, Veracruz, México \\ Corresponding Author: César Meiners-Mandujano \\ Email address: cmeiners@uv.mx
}

The common octopus of the Veracruz Reef System (VRS, southwestern Gulf of Mexico) has historically been considered as Octopus vulgaris, and yet, to date, no study including both morphological and genetic data has tested that assumption. To assess this matter, 52 octopuses were sampled in different reefs within the VRS to determine the taxonomic identity of this commercially-valuable species using an integrative taxonomic approach through both morphological and genetic analyses. Morphological and genetic data confirmed that the common octopus of the VRS is not $O$. vulgaris and determined that it is, in fact, the recently described Octopus insularis. Morphological measurements, counts, indices, and other characteristics such as specific colour patterns, closely matched what had been reported for $O$. insularis in Brazil. In addition, sequences from cytochrome oxidase I (COI) and 16S ribosomal RNA ( $r 16 S$ ) mitochondrial genes confirmed that the octopus from VRS are in the same highly-supported clade as $O$. insularis from Brazil. Genetic distances of both mitochondrial genes as well as of cytochrome oxidase subunit III (COIII) and novel nuclear rhodopsin sequences for the species, also confirmed this finding $(0-0.8 \%)$. We discuss our findings in the light of the recent reports of octopus species misidentifications involving the members of the "O. vulgaris species complex" and underscore the need for more morphological studies regarding this group to properly address the management of these commercially-valuable and similar taxa. 
1 An integrative taxonomic approach reveals Octopus insularis as the dominant species in the 2 Veracruz Reef System (southwestern Gulf of Mexico)

3 Roberto González-Gómez ${ }^{1,2}$, Irene de los Angeles Barriga-Sosa ${ }^{3}$, Ricardo Pliego-Cárdenas ${ }^{4}$,

4 Lourdes Jiménez-Badillo ${ }^{2}$, Unai Markaida ${ }^{5}$, César Meiners-Mandujano ${ }^{2}$ and Piedad S. Morillo-

$5 \quad$ Velarde 6

6 Posgrado en Ecología y Pesquerías, Universidad Veracruzana, Boca del Río, Veracruz,

7 México;

$8 \quad{ }^{2}$ Instituto de Ciencias Marinas y Pesquerías, Universidad Veracruzana, Boca del Río, Veracruz,

9 México;

$10{ }^{3}$ Departamento de Hidrobiología, Universidad Autónoma Metropolitana-Iztapalapa, Ciudad de

11 México, México;

$12{ }^{4}$ División de Estudios Profesionales, Facultad de Ciencias, Universidad Nacional Autónoma de

13 México, Ciudad de México, México;

14 5aboratorio de Pesquerías Artesanales, El Colegio de la Frontera Sur (CONACyT), Lerma,

15 Campeche, México;

$16{ }^{6}$ CONACyT-Instituto de Ciencias Marinas y Pesquerías, Universidad Veracruzana, Boca del

17 Río, Veracruz, México

18

19 Corresponding Author:

20 César Meiners-Mandujano ${ }^{2}$

21 Av. Hidalgo \#617, Col. Río Jamapa, Boca del Río, Veracruz, 94290, México

22 Email address: cmeiners@uv.mx 


\section{ABSTRACT}

33 The common octopus of the Veracruz Reef System (VRS, southwestern Gulf of Mexico) has

34 historically been considered as Octopus vulgaris, and yet, to date, no study including both morphological and genetic data has tested that assumption. To assess this matter, 52 octopuses were sampled in different reefs within the Veracruz Reef System to determine the taxonomic identity of this commercially-valuable species using an integrative taxonomic approach through both morphological and genetic analyses. Morphological and genetic data confirmed that the common octopus of the Veracruz Reef System is not $O$. vulgaris and determined that it is, in fact, the recently described Octopus insularis. Morphological measurements, counts, indices, and other characteristics such as specific colour patterns, closely matched what had been reported for O. insularis in Brazil. In addition, sequences from cytochrome oxidase I (COI) and 16S ribosomal RNA (r16S) mitochondrial genes confirmed that the octopus from Veracruz Reef System are in the same highly-supported clade as $O$. insularis from Brazil. Genetic distances of both mitochondrial genes as well as of cytochrome oxidase subunit III (COIII) and novel nuclear rhodopsin sequences for the species, also confirmed this finding (0-0.8\%). We discuss our findings in the light of the recent reports of octopus species misidentifications involving the members of the "O. vulgaris species complex" and underscore the need for more morphological studies regarding this group to properly address the management of these commercially-valuable and similar taxa.

(1)




\section{INTRODUCTION}

Many octopus fisheries are of high economic local importance (Jiménez-Badillo, 2010; Rosas et al., 2014). Despite this fact, in many cases, the taxonomic identity of the targeted species remains unknown or has been long taken for granted because official fishery statistics do not attempt to distinguish different species (Domínguez-Contreras et al., 2018). FAO catch statistics currently include only four octopus species names, Octopus vulgaris Cuvier 1797, Octopus maya Voss \& Solís-Ramírez 1966, Eledone cirrhosa (Lamarck, 1798) and Eledone moschata (Lamarck, 1798), with the rest being classified as unidentified octopuses (Norman, Finn \& Hochberg, 2016). However, as many finfish stocks are collapsing worldwide, commercial interests are shifting towards the exploitation of cephalopod resources. Therefore, as the value of octopus fisheries continues to increase, the need for rigorous taxonomic knowledge is greater than ever before (Norman \& Hochberg, 2005). This is particularly important in Mexico because it is the largest American octopus producer (Norman \& Finn, 2016).

The difficulty of correctly assigning the taxonomic identity of octopus species partially lies in the existence of several species complexes comprising taxa that share superficial morphological similarity (Norman, 1992; Roper, Gutierrez \& Vecchione, 2015; Amor et al., 2016; Gleadall, 2016) and that are currently treated under the catch-all species names "vulgaris", "macropus" and "defilippi" (Norman \& Hochberg, 2005). Moreover, the genus Octopus has been used, to date, to include the vast majority of described shallow-water octopuses, including taxa designated as "unplaced" (Norman \& Hochberg, 2005; Norman, Finn \& Hochberg, 2016). However, recent molecular studies have proven that the genus Octopus is polyphyletic and contains a number of distinct and divergent clades (Guzik, Norman \& Crozier, 2005; AcostaJofré et al., 2012). In this paper, we refer to the genus Octopus as the group of species including the "Octopus vulgaris species complex" and its close relatives, sensu Norman, Finn \& Hochberg (2016). The "Octopus vulgaris species complex" currently comprises the type species of the group, Octopus vulgaris sensu stricto (s. s.), found in the Mediterranean Sea, and the central and north-east Atlantic Ocean, plus four more "types" inhabiting different geographical areas; type I (tropical western central Atlantic Ocean), type II (subtropical south-west Atlantic Ocean), type III (temperate South Africa and the southern Indian ocean) and type IV (subtropical/temperate east Asia) (Amor et al., 2016; Norman, Finn \& Hochberg, 2016). The representative of the 
89

90

91

92

93

94

95

96

97

98

complex in Mexican Atlantic waters, Octopus "vulgaris" type I, is of high fisheries value, with annual catches averaging almost 7,000 $\mathrm{t}$ for the last ten years (CONAPESCA, 2018).

Despite the similarities of this closely-related taxa, in recent years, more detailed and consistent diagnoses and descriptions have described new octopus species, e.g. Octopus insularis Leite \& Haimovici, 2008, and Octopus tayrona Guerrero-Kommritz \& Camelo-Guarin, 2016; as a consequence, it is now known that the Octopus "vulgaris" type I is a group that comprises several species. Most species in this complex have yet to be distinguished using morphological and meristic characters (Amor et al., 2016). A recent assessment in different coastal and oceanic regions along the Tropical Northwestern Atlantic and Tropical Southwestern Atlantic revealed that several commercially-fished octopus specimens previously identified as $O$. vulgaris were being mislabeled and were in fact either $O$. maya or $O$. insularis, thus proving the common misidentification that often occurs among the exploited octopus species in the area (Lima et al., 2017). Proper identification of organisms is necessary to monitor biodiversity at any level (Vecchione \& Colette, 1996) and it is particularly important in the case of commerciallyexploited species because it allows the effective management of their stocks by considering specific biological features and thus defining particular conservation proposals to prevent overexploitation (Ward, 2000; Lima et al., 2017).

Misidentification among the species of the genus Octopus has been attributed to a general external resemblance as well as to similar skin texture and colour patterns (Norman \& Hochberg, 2005). However, despite the superficial morphological similarity among the species conforming the "Octopus vulgaris species complex", recent studies have demonstrated that closely related species can be identified based on discrete phenotypic differences (e.g. Huffard \& Hochberg, 2005; Leite et al., 2008; Gleadall, 2016). Recently, Amor et al. (2016) carried out the most comprehensive morphological and molecular-based assessment of the $O$. vulgaris species complex to date and found that all members of the group could be distinguished based on morphological analyses in which male morphology, (e.g. sexual traits) proved to be a more reliable indicator of species-level relationships in comparison with female morphology. As noted by Pomiankowski \& Moller (1995), sexual traits (e.g. the hectocotylus), are usually more phenotypically variable than non-sexual traits among close relatives, making them ideal characters to distinguish between species (Amor et al., 2016). 
In the southwestern Gulf of Mexico, the important shallow-water octopus fishery

operating in the Veracruz Reef System (VRS) has historically been attributed to O. vulgaris (e.g. Jiménez Badillo \& Castro Gaspar, 2007; Méndez Aguilar, Jiménez Badillo \& Arenas Fuentes,

122

123

124

125

126

127

128

129

130

131

132

133

134

135

136

137

138

139 2007; Jiménez-Badillo et al., 2008). However, Flores-Valle et al. (2018) determined the occurrence of $O$. insularis in the Veracruz Reef System and suggested that the common octopus of this system might not be $O$. vulgaris but $O$. insularis instead, originally described in Brazil. The pitfalls associated with a single approach when trying to assign the status of a certain taxon can be avoided by using an integrative taxonomic approach, which aims to delimit the units of life's diversity from multiple and complementary perspectives (Dayrat, 2005). Thus, this approach overcomes biases associated to individual lines of evidence, increasing the information on which taxonomic hypotheses are tested (Chesters et al., 2012). In accordance, the aim of this study was to make a comprehensive description of the Veracruz Reef System common octopus following an integrative taxonomic approach to clarify its taxonomic status by means of both morphological and genetic analyses, including sequences from three mitochondrial (COI, COIII, r16S), and one nuclear region, rhodopsin.

\section{MATERIAL AND METHODS}

Collection sites

The study area lies within the Veracruz Reef System National Park, which is located in the southwestern region of the Gulf of Mexico, off the coast of Veracruz, between $19.04^{\circ}$ $19.26^{\circ} \mathrm{N}$ and $95.77^{\circ}-96.20^{\circ} \mathrm{W}$ and includes 28 reefs and six cayes and islands in an area of 65,516 ha (DOF, 2012, 2017). A total of 52 octopuses were randomly selected from the commercial catches of the artisanal fishery between May and November 2017. All specimens were collected by hand or using a hook while snorkeling in shallow waters (up to $3 \mathrm{~m}$ ) of the reef lagoon and adjacent areas of eight reefs within the Veracruz Reef System: Enmedio, Anegada de Afuera, Anegada de Adentro, Cabezo, Chopas, Verde, Pájaros and Ingenieros (Fig. 1). These reefs were selected to have a good sampling representation of both northern and southern reef subsystems, located off the city of Veracruz and the village of Antón Lizardo respectively and divided by the outlet of the Jamapa River (Horta-Puga, 2003). Oceanographic characteristics in the reefs are given by the Gulf Common Water, with a mean salinity of 36.5 PSU and temperatures between $21.2{ }^{\circ} \mathrm{C}$ and $30.0{ }^{\circ} \mathrm{C}$ (Mateos-Jasso et al., 2012). The benthic habitat in the 
150 sampling sites is characterized by the presence of numerous scattered patches of seagrass, sand, 151 coral rubble, several species of algae, isolated branching and massive corals and an underlying 152 rocky basement constituted by remains of Porites porites (Pallas, 1766) mixed with Siderastrea 153 radians (Pallas, 1766) and Pseudodiploria clivosa (Ellis \& Sollander, 1786) (Chávez, Tunnell \& 154 Withers, 2007).

155

156

Morphological study

Octopus specimens used for morphological analysis were ice-stored in zip-lock plastic bags for $48 \mathrm{~h}$, then fixed in 10\% formalin and finally preserved in $70 \%$ ethanol after rinsing in running tap water. The measurements and indices used for the description follow Roper \& Voss (1983) and Norman, Hochberg \& Lu (1997) with the exception of the arm-length index (ALI), which is defined here as length of the longest arm as a percentage of the total length (not mantle length) and sucker counts, which included all suckers of intact arms instead of only those in the basal half of the arms. Reproductive terminology follows Huffard \& Hochberg (2005). Web depth values of sectors B, C and D are the mean value of right and left sides. Abbreviations of measurements and indices are as follows: TW: total wet weight; TL: total length; ML: dorsal mantle length; MWI: mantle width index (mantle width/ML $\times 100)$; MAI: mantle arm index (ML/longest arm length $\times 100) ;$ HWI: head width index (head width/ML $\times 100) ;$ AL: arm length (of intact arms, measured from mouth to the tip of the arm over the row of suckers); ALI: arm length index (arm length/TL $\times 100) ; \mathrm{AW}$ : arm width; AWI: arm width index (arm width at the widest point of the stoutest arm/ML $\times 100)$; ASC: arm sucker count; HASC: hectocotylized arm sucker count; GiLC: gill lamellae count (number of outer gill lamellae including the terminal

172 lamella); FLI: funnel length index (funnel length/ML $\times 100) ; \mathrm{HAL}$ : hectocotylized arm length;

173 HcAI: hectocotylized arm index (hectocotylized arm length/ML × 100); OAI: opposite arm index 174 (length of hectocotylized arm as a percentage of its fellow arm on opposite side); LL: ligula 175 length; LLI: ligula length index (ligula length/HAL $\times 100)$; CL: calamus length; CLI: calamus 176 length index (calamus length/ligula length $\times 100$ ); nSD: normal sucker diameter; nSDI: normal 177 sucker diameter index (largest normal sucker diameter/ML $\times 100$ ); eSD: enlarged sucker 178 diameter; eSDI: enlarged sucker diameter index (largest enlarged sucker diameter/ML $\times 100$ ); 179 ELD: eye lens diameter; EDI: eye lens diameter index (eye lens diameter/ML × 100); WD: web 180 depth; WDI: web depth index (web depth/ML × 100); TOL: terminal organ length; TOLI: 
181 terminal organ length index (terminal organ length/ML $\times 100$ ); SpL: spermatophores length;

182 SpLI: spermatophore length index (length of spermatophore/ML $\times 100$ ).

183 In all, 52 octopuses were analyzed and their morphological characters recorded.

184 However, morphological and meristic data presented in the results section were based on

185 submature and mature specimens only (e.g. maturity stages II-IV, $\mathrm{n}=18$, Leite et al., 2008;

186 Guerra et al., 2010), because counts and relative measurements in immature specimens undergo

187 considerable change in early growth stages and can cause overlap in otherwise valid diagnostic

188 characters (Norman, Hochberg \& Lu, 1997).

189 The small structures, such as ligula, calamus, radula, spermatophores and eggs were

190 measured with the aid of an ocular micrometer in a binocular microscope (Zeiss Stemi 2000-C).

191 All measurements are in $\mathrm{mm}$ and the weights in $\mathrm{g}$ unless stated otherwise.

192 The sex of the specimens was assigned by the observation of the reproductive organs and

193 the stage of maturity classified as: I (Immature), II (Maturing), III (Mature) and IV (Post-

194 maturation) following the macroscopic scale for stages of gonadal maturity proposed by Lima et 195 al. (2014).

196 Digestive tracts and reproductive organs were dissected in some specimens for 197 examination and description. Illustrations were edited with Adobe Photoshop CS6 from high-

198 resolution photographs taken with a digital camera (Nikon D90). Beaks and radula were

199 photographed after cleaning with a saturation solution on sodium hydroxide $(\mathrm{NaOH})$.

200

201 Statistical analyses of morphological data

202 Preliminary observations suggested the existence of morphological differences between

203 the Veracruz Reef System common octopus and O. vulgaris $s$. $s$. To further investigate these 204 differences, we performed multivariate analysis with PRIMER 7 v7.0.13 (PRIMER-E Ltd)

205 comparing recorded morphological data on the Veracruz Reef System common octopus with

206 published data on $O$. insularis and O. vulgaris s. s. (included in supplementary Table 2 from

207 Amor et al., 2016). In all, 10 morphological traits were compiled in a matrix including

208 information of the three taxa; these were: HWI, CLI, LLI, eSDI, HcAI, HASC, FLI, MWI, WDI

209 and TOLI. Analysis of morphological traits was limited to male specimens to maximize the

210 number of indices and counts used, minding that male morphology has proven a more reliable

211 indicator at a species-level compared to female morphology (Amor et al. 2016). Given that 
212 measurements of some traits could not be obtained for particular individuals because of damage,

213 all missing data were replaced with the mean of that trait for each taxa, as missing data are not

214 permitted in the analysis (Allcock, Strugnell \& Johnson, 2008; Amor et al., 2016).

215 Morphological traits were transformed to zero mean and unit standard deviation, thus allowing

216 for comparisons of traits despite having different measurement scales (Allcock, Strugnell \&

217 Johnson, 2008; Amor et al. 2016). A resemblance matrix based on Euclidean distance was

218 calculated for the normalised traits and a principal coordinate ordination (PCO) plot, with vector

219 overlay using Pearson correlation $>0.6$, was used to visualize the natural groupings of the

220 samples (Roura et al., 2016). The statistical significance of the differences observed in the PCO

221 plot was further tested with a one-way analysis of similarity (ANOSIM) (Allcock, Strugnell \&

222 Johnson, 2008). This test gives an R-value indicative of the difference between samples as well

223 as a p-value for the significance of that difference. $\mathrm{R}$ values close to 1 indicate large differences

224 among samples while values closer to 0 indicate lesser differences (Clarke \& Warwick 2001).

225 The similarity percentage analysis (SIMPER, Clarke, 1993) was used to determine the

226 percentage contribution of each morphological trait to the average square distance between the

227 compared taxa. Results from analyses were deemed significant at $P<0.05$.

228

229 Genetic identification and relationships of octopus specimens

230 To perform the genetic identification of the Veracruz Reef System common octopus,

231 muscle tissue samples from 20 octopuses were preserved in non-denatured $95 \%$ ethanol

232 following the procedure suggested by Wall, Campo \& Wetzer (2014) and maintained at $-4^{\circ} \mathrm{C}$ for

$23372 \mathrm{~h}$ for tissue fixation before processing for DNA extraction. All specimens used for genetic

234 identification were also morphologically analyzed, to strengthen conclusions drawn within an

235 integrative taxonomic approach.

236 Total DNA was extracted from arm tissue using the Wizard ${ }^{\circledR}$ Genomic DNA Purification

237 kit (Promega $\left.{ }^{\circledR}\right)$. PCR amplifications for mitochondrial COI, COIII and r16S genes and the

238 rhodopsin nuclear marker were carried out using QIAGEN® Kit PCR reagent system (Valencia,

$239 \mathrm{CA})$. Each $25 \mu \mathrm{L}$ reaction contained $1.0 \mu \mathrm{L}$ of $\mathrm{MgCl}_{2}(2.0 \mathrm{mM}), 10 \mu \mathrm{M}$ each primer, $200 \mu \mathrm{M}$

240 each dNTP, 2.5X PCR Buffer and 2.5U Taq Polymerase. Primers for COI were those described

241 by Allcock, Strugnell \& Johnson (2008), the COIII ones were from Barriga-Sosa et al. (1995),

242 the r16S ones were those from Simon, Franke \& Martin (1991) and Rhodopsin primers are from 
243 Strugnell (2004). PCR reactions were conducted in a Mycycler (Bio-Rad ${ }^{\circledR}$ ) thermocycler using

244 the annealing temperatures of $50^{\circ} \mathrm{C}$ for rhodopsin and $49^{\circ} \mathrm{C}$ for $\mathrm{COI}, 52^{\circ} \mathrm{C}(\mathrm{r} 16 \mathrm{~S}), 32^{\circ} \mathrm{C}$ for

245 COIII and the following conditions: an initial cycle of denaturing at $94^{\circ} \mathrm{C}$ for $2 \mathrm{~min}$; followed by

24630 cycles at $94^{\circ} \mathrm{C}$ for $45 \mathrm{~s}$, an annealing step for $60 \mathrm{~s}$, and extension step at $72^{\circ} \mathrm{C}$ for $90 \mathrm{~s}$, and

247 finally an extension cycle at $72^{\circ} \mathrm{C}$ for $5 \mathrm{~min}$.

248 Sequencing reactions on both directions were carried out using Macrogen (Korea)

249 services. Additional sequences of several octopod species were obtained from GenBank for

250 comparison. The alignments of the sequences were verified with the respective translation of

251 amino acids for COI, COIII and rhodopsin. Genetic distances were calculated for each gene

252 region using the Tamura-Nei model (Tamura \& Nei, 1993). Bootstrap support was estimated

253 using 500 iterations. All these analyses were implemented in Mega 7.0 (Kumar, Stecher \&

254 Tamura, 2016).

255 JModelTest (Darriba et al. 2012) was used to select the best evolutionary model for each

256 gene region. The appropriate model was chosen based on 'goodness of fit' via the Akaike

257 information criterion. The best fit model for COI was GTR $+\mathrm{I}+\mathrm{G}$ and TIM3+G (topology

258 GTR + G) for r16S. Phylogenetic reconstruction was conducted by using each gene separately.

259 Bayesian Inference (BI) was run using MrBayes 3.1.2. (Ronquist \& Huelsenbeck, 2003), only for

260 COI and r16S genes, because of limited or absence of homologous sequences in GeneBank for

261 O. insularis COIII and rhodopsin, respectively. "Octopus” cyanea Gray, 1849 was selected as

262 outgroup on the basis of their close phylogenetic relation to the internal group (Amor et al. 2014,

263 2015). Analyses were started from random trees, and it was run for 5 million generations for

264 each data set and sampling the Markov chain every 1000 generations. The program Tracer v1.3

265 (Rambaut et al. 2014) was then used to ensure Markov chains had reached stationarity and to

266 determine the correct 'burn-in' for the analysis. The analysis converged after 500000 generations

267 with ESS values $>200$ for all parameters.

268

269

\section{RESULTS}

270

Diagnosis of the Veracruz Reef System common octopus

271

Medium to large sized animals with ML up to $189 \mathrm{~mm}$ and TW up to $1,811 \mathrm{~g}$;

272 hectocotylized arm bearing 103-146 suckers; small ligula (LLI 0.92-1.65) and relatively long

273 calamus (CLI 40.79-58-56); slightly enlarged suckers in mature males (eSDI 8.87-13.75); 8-11 
274 lamellae on outer demibranch; one large papilla and several smaller ones over each eye. Live

275 animals creamish in colour, showing a distinct red/white reticule in the inner of arms when

276 hidden in the den and still visible in freshly dead specimens. No ocellus present.

277

278

279

280

281

282

283

284

285

286

287

288

289

290

291

292

293

294

295

296

297

298

299

300

301

302

303

304

Morphological description of the Veracruz Reef System common octopus

The following description is based on 14 males and four females, all of them in maturity stages II-IV. Most relevant counts, measurements and indices are given in Tables 1 and 2 and in Table S1.

Medium to large-sized organisms (up to $696 \mathrm{~mm}$ TL and 1,811 $\mathrm{g}$ TW) with muscular body (Fig. 2A). Mantle wide (max $189 \mathrm{~mm}$ ML) and saccular. Head wide (HWI 27.67-50.13) and pallial aperture moderately wide (PAI 33.45-61.66). Funnel tubular (FLI 26.79-49.47) with funnel organ well defined and W shaped (Fig. 2B). Most common arm formula is: IV $>$ II $>$ III $>I$ (right) and IV $>$ III $>$ I $>$ II (left). Arms are wide (AWI 12.82-23.15) and relatively short (ALI 77.5387.22). Third right arm in males hectocotylized, bearing 103-146 suckers and normally shorter than opposite one (OAI 77.06-90.75). Spermatophoric groove well defined, running ventrally along the arm and ending at a relatively big calamus (CLI 40.79-58.56). Ligula small (LLI 0.921.65). Suckers in normal arms between 103 and 267 (nSDI 7.05-10.42). Mature males have enlarged suckers in arms II and III, normally between rows 13 and 16, more conspicuous in large-sized specimens (eSDI 8.87-13.75). Females do not have them. Stylets present, wide and hockey club-shaped (Fig. 2D). Web moderately deep (WD ; WDI 16.35-24.91), typical web formula $\mathrm{D}>\mathrm{C}>\mathrm{E}>\mathrm{B}>\mathrm{A}$. Gills with 8-11 lamellae per outer demibranch.

Digestive system consisting of a big buccal mass with conspicuous anterior salivary glands, narrow oesophagus, big triangular posterior salivary glands, slender crop, wide stomach and spiral caecum with three whorls (Fig. 3A). The ink sac is embedded in the digestive gland. Intestine long, muscular. Anal flaps present. The beaks are strong, with prominent rostrum and wide wings (Fig. 3C, D). Radula with seven teeth and two marginal plates per transverse row. Rachidean tooth with one lateral cusp at each side and symmetric seriation every three teeth $\left(\mathrm{A}_{3}\right)$ (Fig. 3B, E).

Female reproductive system consisting of a large and round ovary in mature females, with thin oviducts and oviductal glands small and rounded (Fig. 4A). Eggs small; mean length and width of immediately spawned eggs were $2.23 \pm 0.05 \mathrm{~mm}$ and $0.92 \pm 0.06 \mathrm{~mm}$ respectively 
305 (mean $\pm \mathrm{SD}$ ). Male reproductive system comprises a large testis followed by a long and thin vas 306 deferens packed in a membranous sac. Spermatophoric gland opens in an atrium with the

307

308

309

310

311

312

313

314

315

316

317

318

319

320

321

322

323

324

325

326

327

328

329

330

331

332

333

334

335

accessory gland and the spermatophore storage sac (maximum 70 spermatophores). The terminal organ is short and has a rounded diverticulum (Fig. 4B). Spermatophores are medium sized (SpLI 28.06-38.68, Fig. 4C).

In fixed organisms, skin presents well defined polygonal patches with distinct grooves and is covered in papillae in the dorsal surface; ventrally, this occurs to a lesser extent. Colour varies from yellowish to violet dorsally and from cream to grey-brown ventrally. There is one large cirrus and some smaller ones over each eye (Fig. 5A). In live specimens colour varies from pale yellow to reddish-brown, being cream the most common. Among the most distinctive chromatic components observed in live or fresh specimens we could observe: dark/light bars alternating around the eye, a red/white reticulate pattern in the ventral part of the arms when the animal was hidden in the den, and a blue-green circle around the eye (Fig. 5B).

\section{Morphological analysis}

Multivariate combinations of morphological traits were successful in distinguishing among the three taxa compared. In the PCO plot, the first two components explained $72 \%$ of the total variance (Fig. 6). The first component explained 57.8\% of the variance and was strongly correlated with eSDI (loading: 0.906), TOLI (0.888), HWI (0.871) and HASC (0.863). The second component explained $14.2 \%$ of the variance and was correlated mainly with CLI (0.807) and LLI (0.623). The PCO plot showed a complete differentiation between the Veracruz Reef System common octopus and $O$. vulgaris $s$. s., mainly along the first component of the PCO (Fig. 6) with Octopus vulgaris s. s. showing high PC1 loadings attributed to higher sucker numbers in the hectocotylized arm and relatively larger enlarged suckers. Octopus insularis and the Veracruz Reef System common octopus showed the least discrimination, although the former had relatively higher HWI, WDI and MWI than the latter. ANOSIM test confirmed the significance of the observed differences (Global $\mathrm{R}=0.751, \mathrm{p}<0.001)$ and pairwise comparisons showed the existence of significant differences in morphological traits between all taxa pairs, indicating they were greatest between the Veracruz Reef System common octopus and $O$. vulgaris s. $s .(\mathrm{R}=0.943, \mathrm{p}<0.001)$, intermediate between $O$. vulgaris $s$. $s$. and $O$. insularis from Brazil $(\mathrm{R}=0.664, \mathrm{p}<0.001)$ and smallest between this latter taxon and the Veracruz Reef 
336 System common octopus $(\mathrm{R}=0.66, \mathrm{p}<0.001)$. SIMPER analysis showed that the main

337 morphological traits responsible for the differences between $O$. vulgaris $s$. $s$. and both $O$.

338 insularis from Brazil and the Veracruz Reef System common octopus were reproductive traits

339 (e.g. HASC, TOLI, eSDI). In contrast, the main traits differentiating these last taxa were related

340 to the shape of the web and the mantle: WDI and MWI respectively, accounting for nearly $40 \%$

341 of the observed differences (Table 3).

342

343 Genetic identification and relationships of octopus specimens

344 Sequences from 20 specimens (GenBank accession numbers: MH550422-MH550467)

345 resolved two and three haplotypes for $\operatorname{r16S}(400 \mathrm{pb}, \mathrm{N}=18)$ and COI (605 pb, N=18),

346 respectively. Haplotype 1 for $\mathrm{r} 16 \mathrm{~S}(\mathrm{~N}=17)$, was a shared haplotype with $O$. insularis from the

347 northern coast of Brazil (KF843956-7, 60-62, 64-66), whereas Haplotype 2 was a novel one for

348 this study. For COI, two haplotypes were shared with those reported elsewhere. For instance,

349 Haplotype $1(\mathrm{~N}=13)$, was a shared type with $O$. insularis from the coast of Brazil (KX611855,

350 KF844000-1, 5, 7, 9 \& 19). Haplotype $2(\mathrm{~N}=4)$ was shared with type KX611857 and also one

351 novel haplotype was identified for the Veracruz Reef System. For COIII, 9 specimens from the

352 Veracruz Reef System shared a unique haplotype from GenBank (AJ012123). The only

353 haplotype resolved for the nuclear gene rhodopsin is novel for the species (MH550449), since

354 there are no homologous sequences for O. insularis in GenBank.

355 The COI, COIII, r16S and rhodopsin genetic distances between the analyzed specimens

356 from the Veracruz Reef System, and $O$. insularis from Brazil resolved from no genetic

357 divergence to very low values between them ( 0.0 to $0.6 \%$, see Table 4$)$. One novel rhodopsin

358 haplotype was resolved for the species with genetic distances from 0.5 to $1.7 \%$ with respect to

359 the species that conform the American octopus clade (O. mimus Gould, 1852, O. bimaculatus

360 Verrill, 1883 and O. bimaculoides Pickford \& McConnaughey, 1949, see Table 4).

361 The phylogenetic topologies for both mitochondrial regions COI and r16S, recovered two

362 main clades ( $\mathrm{pp}=0.9$ ), one of them containing species from America (Octopus bimaculatus, $O$.

363 bimaculoides, O. insularis, O. maya and O. mimus) and the other one containing O. vulgaris

364 types, O. sinensis d'Orbigny, 1834, O. tetricus Gould, 1852 and O. hummelincki Adam, 1936.

365 All specimens collected in the Veracruz Reef System fell within a highly supported 
366

367

368

369

370

371

372

373

374

375

376

377

378

379

380

381

382

383

384

385

386

387

388

389

390

391

392

393

394

395

monophyletic clade with both gene regions ( $\mathrm{pp}=1$ and $\mathrm{pp}=0.88$, for COI and $\mathrm{r} 16 \mathrm{~S}$, respectively) along with $O$. insularis individuals from Brazil (Figs. 7, 8).

\section{DISCUSSION}

Our integrative taxonomic study confirms that the Veracruz Reef System common octopus is Octopus insularis. The measurements, counts and indices of octopuses analyzed in this study, not previously distinguished from $O$. vulgaris, as well as the shape and size of beaks, stylets, spermatophores, eggs and other features such as specific colour patterns almost entirely match those reported by Leite et al. (2008), Leite \& Mather (2008) and Amor et al. (2016) for $O$. insularis in Brazil (Figs. 2-5, Table 5). The few differences found, as the smaller eSDI, the smaller MWI or the smaller WDI, could be attributed to local adaptation (Guerra et al., 2010) or, perhaps, to slight tissue deformations derived from the fixation and preservation process (Allcock et al., 2011). In fact, SIMPER analysis revealed that differences between the VRS common octopus and $O$. insularis specimens from Brazil were mainly attributed to traits related to the shape of the web and mantle (e.g. WDI and MWI), which are more likely to suffer from fixation and preservation artefacts.

Moreover, Amor et al. (2016) investigated the morphological relationships among seven phylogenetic clades of the "Octopus vulgaris species complex" and found several significant morphological differences among sampling localities of conspecifics, considering them to represent population-level differences. Specimens analyzed in the present study are close to the maximum dimensions reported in Brazil: $2 \mathrm{~kg}$ TW, $700 \mathrm{~mm}$ TL and $190 \mathrm{~mm}$ ML (Lima et al., 2017). Colour patterns and skin texture observed in our specimens exactly match what has been previously reported for $O$. insularis. This species shares the 'patch-and-groove' topology with several other Octopus spp. (Norman, Finn \& Hochberg, 2016), however, the observation of specific colour patterns (e.g. the red/white reticulate skin pattern observed in the inner part of the arms when the octopuses were hidden in the den as well as the alternating light/dark bars and the blue-green ring around the eye; Fig. 5) allows a rapid identification of the species (Leite et al., 2008; Leite \& Mather, 2008).

Our morphological analysis clearly differentiated the Veracruz Reef System common octopus from O. vulgaris s. s., mainly based on sexual traits such as HASC, TOLI and eSDI (Fig. 
396

397

398

399

400

401

402

403

404

405

406

407

408

409

410

411

412

413

414

415

416

417

418

419

420

421

422

423

424

425

426

6, Table 3). These results support the observations of Amor et al. (2016), whom report that the main morphological differences among members of the $O$. vulgaris species complex were driven by male sexual traits. Moreover, our morphological data on the Veracruz Reef System common octopus strongly differ from the data reported for $O$. vulgaris $s$. s. elsewhere (e.g. Mangold, 1988; Otero et al., 2007; Amor et al., 2016) (Table 5). The Veracruz Reef System common octopus has a smaller size (189 $\mathrm{mm}$ vs. $350 \mathrm{~mm}$ max ML), fewer suckers in the hectocotylized arm (HASC 103-146 vs. 156-183), smaller enlarged suckers (eSDI 8.87-13.75 vs. 16.67-25.60), smaller calamus (CLI 40.79-58.56 vs. 40.39-67.55), larger ligula (LLI 0.92-1.65 vs. 0.66-1.29), shallower web (WDI 16.35-24.91 vs. 82.09-146.63) and smaller spermatophores (SpLI 28.0638.68 vs. 31.00-81.00). Another notable difference between both species is the absence of enlarged suckers in O. insularis females while they are present in O. vulgaris (Mangold, 1998, Norman, Finn \& Hochberg, 2016).

The common octopus of the Veracruz Reef System can also be differentiated from similar taxa known to inhabit the western Atlantic based on several morphological characters. In this sense, O. insularis from Veracruz can be distinguished from O. tayrona from the Colombian Caribbean based on the presence of enlarged suckers, larger size of mature specimens (189 mm vs. $130 \mathrm{~mm}$ max ML), larger calamus (CLI 40.79-58.56 vs. 20.00-50.00), narrower mantle (max MWI 80.21 vs. 112.50) and shallower web (max WDI 24.91 vs. 82.40) (Table 5). Octopus insularis and O. maya Voss \& Solís, 1966, an abundant species endemic to the Campeche Bank, southeastern Gulf of Mexico, are genetically considered sister species (Sales et al., 2013). However, the latter is immediately identified by the presence of a dark ocellus below each eye, and its large eggs (Voss \& Solís-Ramírez, 1966). Octopus briareus Robson, 1929 is a smaller species (120 mm max ML) and has a larger ligula (LLI 3-4), smaller calamus (CLI 28-32), fewer gill lamellae (6-8) and a distinct iridescent blue-green colour in life (Voss \& Toll, 1998). Octopus hummelincki, a common reef-associated octopus, is smaller (72 mm max ML), and possesses a larger ligula (LLI 3-5), fewer gill lamellae (5-9) and a pair of ocelli consisting of a dark central spot inside a conspicuous iridescent blue ring (Voss \& Toll, 1998). Lastly, the artisanal fishermen of the Veracruz Reef System sometimes manage to capture specimens of the locally known as "pulpo malario", which so far is thought to be Callistoctopus macropus (Risso, 1826). However, in light of its original description from the Mediterranean Sea, a critical revision has been suggested for this taxa in the western Atlantic (Leite et al., 2008). The species 
427 can be easily differentiated from $O$. insularis by its brick red colour with distinct pattern of white

428 spots on dorsal mantle, head and arms as well as by its larger ligula, longer arms, shallower web 429 and very reduced stylets (Mangold, 1998).

430 The resolved COI and r16S highly supported clades, one including the monophyletic 431 clade, which we refer to as the American Octopus clade, conformed by Octopus bimaculatus, O. 432 bimaculoides, O. insularis, O. maya and O. mimus, along with the specimens from the Veracruz 433 Reef System; and the O. vulgaris clade, are concordant results to those that have been previously 434 reported elsewhere (Leite et al., 2008; Sales et al. 2013; Lima et al. 2017; Flores-Valle et al. 435 2018). These latest reports resolved two main and highly supported clades (O. insularis and $O$. 436 vulgaris clades).

437 The genetic similarities found between the specimens analyzed from the southern reefs 438 Isla de Enmedio (IE) and Anegada de Afuera (AA) of the Veracruz Reef System and O. insularis 439 from Brazil also support the identity of the formers as $O$. insularis, as they share haplotypes in 440 all mitochondrial genes analyzed (e.g. average genetic distance $0.0 \%$ to $0.6 \%$; see Table 4 ). 441 Most samples from the Veracruz Reef System shared r16S Haplotype 1 with O. insularis from 442 the northern coast of Brazil (Sales et al., 2013); COI Haplotype 1 is also shared with O. insularis 443 from the Brazilian coast and the Fernando de Noronha archipelago (Sales et al., 2013; Lima et 444 al., 2017), whereas Haplotype 2 is shared with O. insularis from the São Pedro and São Paulo 445 archipelago (Lima et al. 2017). The only Haplotype resolved by COIII, is shared with haplotype AJ012123, from Brazil (Warnke et al. 2004). Unfortunately, the lack of available rhodopsin sequences of $O$. insularis from Brazil in GenBank precluded a comparison with the specimens from Veracruz Reef System. However, the nuclear genetic distance between $O$. vulgaris and $O$. insularis was the highest among congeners (2.4\% average genetic distance). This result supports the distinction of Veracruz Reef System specimens from O. vulgaris.

In this study, we proved, based on an integrative taxonomic approach, that the common octopus that supports the main cephalopod fishery of the southwestern Gulf of Mexico is $O$. insularis. This fact is consistent with the first record of this species in the Gulf of Mexico by Flores-Valle et al. (2018). These authors reckon, however, the need for a detailed morphological description to demonstrate that the Mexican and Brazilian taxa are conspecifics. This matter has been fully resolved in the present study by combining both morphological and genetic analyses. 

as the common octopus of the Veracruz Reef System (e.g. Jiménez-Badillo \& Castro-Gaspar, 2007; Jiménez-Badillo, 2010; Jiménez, 2013) should in fact be attributed to O. insularis. It has been suggested that $O$. insularis and $O$. vulgaris, although in sympatry, might be occupying different niches related to depth and temperature in northeastern Brazil, with the former inhabiting shallower and warmer waters (Lima et al., 2017). The reason for this difference seems to be the higher tolerance of $O$. insularis to both salinity increases and decreases, as evidenced by osmotic experiments (Amado et al., 2015). This explanation is consistent with the presence of O. insularis in estuaries of small rivers and in tide pools in Brazil, where salinity and temperature can vary greatly (e.g. 36-42 PSU and $24-36^{\circ} \mathrm{C}$ ) (Fonseca et al., 2012; Lima, 2017) and with its occurrence in the shallow waters of the Veracruz Reef System, where significant changes in salinity (e.g. from 32 to $39 \mathrm{PSU}$ ) and temperature (e.g. from 19.6 to $30^{\circ} \mathrm{C}$ ) can occur as a consequence of high evaporation or local rivers discharge, especially under the influence of strong winds (Salas-Monreal et al., 2009; Avendaño-Alvarez et al., 2017).

The Caribbean Sea has recently been suggested by Lima (2017) as an origin area of $O$. insularis, which presumably diverged from other Octopus spp. after the uplift of the Panama Isthmus. The fact that $O$. insularis is commonly found within the Veracruz Reef System in shallow waters along the coast and on many reef lagoons, supports the hypothesis of a wide distribution of the species linked to a high dispersal potential, including the shallow waters of the continental shelves, banks, seamounts and islands, in the western Atlantic Ocean (Leite et al., 2008; Lima et al., 2017). The Veracruz Reef System constitutes, up to now, the north-western limit of a well-established $O$. insularis' population, however, additional sampling within the Gulf of Mexico and other areas along the western Atlantic coast could expand its geographical dominance in tropical waters and include for example the Lobos-Tuxpan Reef System, the Alacranes Reef System, or the Mesoamerican Reef System. Indeed, a priori in situ identifications based on colouration patterns (see Fig. 9) point to the presence of the species in the coral reef system of Puerto Morelos, Mexico, just a few km south of Isla Mujeres, where another specimen was morphologically identified in the field as O. insularis (Lima et al., 2017). Nevertheless, proving the existence of a population there would require formal analysis of 486 octopus specimens across the area to determine genetic cohesion. 

the state of Veracruz has implications regarding the taxonomic composition of Mexican octopus fishery data. Until Voss \& Solís-Ramírez's (1966) description of O. maya, a large size holobenthic octopus endemic to the shallow waters of the Yucatan peninsula, all similar-sized octopuses captured in the Mexican Atlantic were considered as O. vulgaris. As a result of the significant dominance of $O$. maya in commercial landings, management policies for the Mexican Atlantic octopus fishery have been based on its biology since the 80's (e.g. DOF, 2012, 2014). In spite of the existence of a separate fishery at the Veracruz Reef System, its peculiarities have only been recently recognized, with the establishment of separate management measures such as different fishing gears and closures (DOF, 2016). Differentiation between $O$. vulgaris and $O$. maya was somewhat easier that the one concerning $O$. insularis because $O$. maya does not have paralarval stage and lays fewer but much larger eggs (Voss \& Solís-Ramírez, 1966). The superficial similarities between $O$. vulgaris and $O$. insularis posed more difficulties assessing the taxonomic identity of the latter species and made it necessary to conduct detailed morphological and genetic analyses in order to differentiate them. Consequently, minding that $O$. insularis is the main species captured in the southwestern Gulf of Mexico, we suggest that it should be included in the statistics as being responsible for a significant amount of the total catch taken by Mexican fishers and reported through FAO as Octopus “vulgaris” type I (FAO, 2016; Norman et al., 2016). Moreover, the most recent studies dealing with $O$. vulgaris type I identifications have shown that the specimens had been misidentified in all cases, actually grouping in the same clade as O. insularis, O. maya, or O. vulgaris type II from Brazil (Lima et al., 2017; Flores-Valle et al., 2018; this study), therefore we cast doubt on the utility of this taxon. In accordance, Mexican management plans concerning the common octopus of the Veracruz Reef System (e.g. DOF, 2012, 2014, 2016) should be readdressed to include $O$. insularis as the targeted species, to achieve more accurate fishery statistics and avoid critical population changes going unnoticed. Misidentifications are common among different commercially-exploited octopus species

513 and are thought to occur due to a lack of knowledge about useful diagnostic characters (Lima et 514 al., 2017). As these authors suggest, identification of specimens should occur immediately after 515 capture, because it is easier to recognize distinct morphological characters in fresh specimens. In 516 line with this, we believe that fishermen and warehouse owners represent an important sector 517 that could make a difference towards successful management plans derived from proper octopus 
518 identification. Hence, the distribution of a visual identification guide of the Veracruz Reef

519 System octopus species (currently in preparation) including colour photographs of live and dead 520 specimens as well as key characters of each species could aid to achieve this important goal.

521

\section{CONCLUSIONS}

523 Proper identification of organisms is necessary to achieve accurate estimates of

524 biodiversity and is particularly important in commercially-exploited species, because it allows

525 the effective management of their stocks. The Veracruz Reef System common octopus has been

526 mistaken with $O$. vulgaris until now due to superficial morphological similarities between both

527 taxa. In this study, following an integrative taxonomic approach, we provide morphological and

528 genetic evidence for the identity of the former as $O$. insularis. Morphological analyses were

529 successful in distinguishing both taxa, with main differences based on male sexual traits such as

530 the number of suckers in the hectocotylized arm or the diameter of enlarged suckers. Hence, our

531 study shows a new case of misidentification involving $O$. vulgaris and highlights the need of

532 more morphological and genetic studies regarding the species of the "Octopus vulgaris complex"

533 in the western Atlantic in order to properly address the management of tropical octopus fisheries

534 and their ecological implications.

535

\section{ACKNOWLEDGEMENTS}

537 This work was made possible by the invaluable help of the artisanal fishermen from the 538 "Cooperativa Arrecifes de Antón Lizardo". The authors wish to express their gratitude to all of 539 them for their hospitality and good company during the sampling trips. Christine Huffard kindly 540 reviewed and improved a preliminary draft of this paper by providing many helpful comments.

541 We thank Paula Rothman for her great effort helping us getting very helpful literature.

542

543 REFERENCES

544 Acosta-Jofré MS, Sahade R, Laudien J, Chiappero MB. 2012. A contribution to the 545 understanding of phylogenetic relationships among species of the genus Octopus 
546

547

548

549

550

551

552

553

554

555

556

557

558

559

560

561

562

563

564

565

566

567

568

569

570

571

572

(Octopodidae: Cephalopoda). Scientia Marina 76: 311-318 DOI

10.3989/scimar.03365.03B.

Allcock AL, Barratt I, Eleaume M, Linse K, Norman MD, Smith PJ, Steinke D, Stevens DW, Strugnell JM. 2011. Cryptic speciation and the circumpolarity debate: a case study on endemic Southern Ocean octopuses using the COI barcode of life. Deep-Sea Research II 58: 242-249 DOI 10.1016/j.dsr2.2010.05.016.

Allcock AL, Strugnell JM, Johnson MP. 2008. How useful are the recommended counts and indices in the systematics of the Octopodidae (Mollusca: Cephalopoda). Biological Journal of the Linnean Society of London 95:205-218 DOI 10.1111/j.10958312.2008.01031.x.

Allcock AL, Strugnell JM, Ruggiero H, Collins MA. 2006. Redescription of the deep-sea octopod Benthoctopus normani (Massy 1907) and a description of a new species from the Northeast Atlantic. Marine Biology Research 2: 372-387 DOI 10.1080/17451000600973315.

Amado EM, Souza-Bastos LR, Vidal EAG, Leite TS, Freire CA. 2015. Different abilities to regulate tissue hydration upon osmotic challenge in vitro, in the cephalopods Octopus vulgaris and O. insularis. Marine and Freshwater Behaviour and Physiology 48: 205-211 DOI 10.1080/10236244.2015.1024078.

Amor MD, Norman MD, Cameron HE, Strugnell JM. 2014. Allopatric speciation within a cryptic species complex of australasian octopus. PLoS ONE 9:e98982 DOI 10.1371/journal.pone.0098982.

Amor MD, Norman MD, Roura A, Leite TS, Gleadall IG, Reid A, Perales-Raya C, Lu CC, Silvey CJ, Vidal EAG, Hochberg FG, Zheng X, Strugnell JM. 2016. Morphological assessment of the Octopus vulgaris species complex evaluated in light of molecularbased phylogenetic inferences. Zoologica Scripta 46: 275-288 DOI 10.1111/zsc.12207.

Avendaño-Alvarez O, Salas-Monreal D, Marin-Hernandez M, Salas-de-Leon DA, MonrealGomez MA. 2017. Annual hydrological variation and hypoxic zone in a tropical coral 
573

574

575

576

577

578

579

580

581

582

583

584

585

586

587

588

589

590

591

592

593

594

595

596

597

598

reef system. Regional Studies in Marine Science 9: 145-155 DOI

10.1016/j.rsma.2016.12.007.

Barriga-Sosa I, Beckenbach K, Hartwick B, Smith MJ. 1995. Molecular phylogeny of five eastern north pacific octopus species. Molecular Phylogenetics and Evolution 4: 163-174 DOI 10.1006/mpev.1995.1016.

Batista AT, Leite TS. 2016. Octopus insularis (Cephalopoda: Octopodidae) on the tropical coast of Brazil: where it lives and what it eats. Brazilian Journal of Oceanography 64: 353-364 DOI 10.1590/s1679-87592016123406404.

Bouth HF, Leite TS, de Lima FD, Oliveira JEL. 2011. Atol das Rocas: an oasis for Octopus insularis juveniles (Cephalopoda: Octopodidae). Zoologia 28: 45-52 DOI 10.1590/S1984-46702011000100007.

Chávez EA, Tunnell JW jr, Withers K. 2007. Coral Reef Zonation and Ecology: Veracruz shelf and Campeche Bank. In: Tunnell W, Chávez EA, Withers K, eds. Coral Reefs of the Southern Gulf of Mexico. Houston: Texas A\&M University Press, 41-67.

Chesters D, Wang Y, Yu F, Bai M, Zhang T-X, Hu H-Y, Zhu C-D, Li C-D, Zhang Y-Z. 2012. The integrative taxonomic approach reveals host specific species in an encyrtid parasitoid species complex. Plos One 7(5): e37655 DOI 10.1371/journal.pone.0037655.

Clarke KR. 1993. Non-parametric multivariate analyses of changes in community structure. Australian Journal of Ecology 18: 117-143 DOI 10.1111/j.14429993.1993.tb00438.x.

Clarke KR, Warwick RM. 2001. Change in marine communities: an approach to statistical analysis and interpretation. 2nd edition. Plymouth: PRIMER-E.

CONAPESCA. 2018. Información Estadística por Especie y Entidad. Mexico: Comisión Nacional de Acuacultura y Pesca. [In Spanish] http://www.conapesca.gob.mx/wb/cona/informacion_estadistica_por_especie_y _entidad (Accessed March 2018). 
599

600

601

602

603

604

605

606

607

608

609

610

611

612

613

614

615

616

617

618

619

620

621

622

623

624

Darriba D, Taboada GL, Doallo R, Posada D. 2012. jModelTest 2: more models, new heuristics and parallel computing. Nature Methods 9:772 DOI 10.1038/nmeth.2109.

Dayrat B. 2005. Towards integrative taxonomy. Biological Journal of the Linnean Society 85: 407-415 DOI 10.1111/j.1095-8312.2005.00503.x.

DOF (DIARIO OFICIAL DE LA FEDERACIÓN). 2012. Acuerdo por el que se modifica el Aviso por el que se da a conocer el establecimiento de épocas y zonas de veda para la pesca de diferentes especies de la fauna acuática en aguas de jurisdicción federal de los Estados Unidos Mexicanos, publicado el 16 de marzo de 1994 para establecer los periodos de veda de pulpo en el Sistema Arrecifal Veracruzano, jaiba en Sonora y Sinaloa, tiburones y rayas en el Océano Pacífico y tiburones en el Golfo de México. 11/06/2012, SAGARPA, Ciudad de México.

DOF (DIARIO OFICIAL DE LA FEDERACIÓN). 2014. Acuerdo por el que se da a conocer el Plan de Manejo Pesquero de pulpo (O. maya y O. vulgaris) del Golfo de México y Mar Caribe. 28/03/2014, SAGARPA, Ciudad de México.

DOF (DIARIO OFICIAL DE LA FEDERACIÓN). 2016. Norma Oficial Mexicana NOM-008SAG/PESC-2015, para ordenar el aprovechamiento de las especies de pulpo en las aguas de jurisdicción federal del Golfo de México y Mar Caribe. 13/04/2016, SAGARPA, Ciudad de México.

DOF (DIARIO OFICIAL DE LA FEDERACIÓN). 2017. Acuerdo por el que se da a conocer el resumen del Programa de Manejo del Área Natural Protegida con categoría de Parque Nacional la zona conocida como Sistema Arrecifal Veracruzano. 22/05/2017, SAGARPA, Ciudad de México.

Domínguez-Contreras JF, Munguia-Vega A, Ceballos-Vázquez BP, Arellano-Martínez M, García-Rodríguez FJ, Culver M, Reyes-Bonilla H. 2018. Life histories predict genetic diversity and population structure within three species of octopus targeted by small-scale fisheries in Northwest Mexico. PeerJ 6:e4295 DOI 10.7717/peerj.4295. 
625 FAO. 2016. Fisheries and Aquaculture Department, Statistics and Information Service FishStatJ:

626 Universal software for fishery statistical time series. Copyright 2016. (Accessed

$62721 / 02 / 2018)$.

628 Flores-Valle A, Pliego-Cárdenas R, Jiménez-Badillo MDL, Arredondo-Figueroa JL, Barriga629 Sosa IDLA. 2018. First record of Octopus insularis (Leite and Haimovici, 2008) in the 630 octopus fishery of a marine protected area in the Gulf of Mexico. Journal of Shellfish $631 \quad$ Research 37: 221-227 DOI 10.2983/035.037.0120.

632 Gleadall IG. 2016. Octopus sinensis d'Orbigny, 1841 (Cephalopoda: Octopodidae): Valid species 633 name for the commercially valuable east Asian common octopus. Species Diversity 21: 634

Horta-Puga G. 2003. Condition of selected reef sites in the Veracruz Reef System (stony corals and algae). Atoll Research Bulletin 496: 360-369.

Huffard CL, Hochberg FG. 2005. Description of a new species of the genus Amphioctopus (Mollusca: Octopodidae) from the Hawaiian Islands. Molluscan Research 25: 113-128.

Huffard CL, Saarman N, Hamilton H, Simison WB. 2010. The evolution of conspicuous 650 facultative mimicry in octopuses: an example of secondary adaptation?. Biological 
651

652

653

654

655

656

657

658

659

660

661

662

663

664

665

666

667

668

669

670

671

672

673

674

675

676

677

Journal of the Linnean Society of London 101: 68-77 DOI 10.1111/j.1095-

8312.2010.01484.x.

Jiménez Badillo ML, Castro Gaspar LG. 2007. Pesca artesanal en el Parque Nacional Sistema Arrecifal Veracruzano, México. In: Granados Barba A, Abarca Arenas LG, Vargas Hernández JM, eds. Investigaciones Cientificas en el Sistema Arrecifal Veracruzano. Campeche: Universidad Autónoma de Campeche, 221-240.

Jiménez-Badillo ML, del Río-Rodríguez RE, Gómez-Solano MI, Cu-Escamilla A, MéndezAguilar D. 2008. Madurez gonádica del pulpo Octopus vulgaris en el Golfo de México: análisis macroscópico y microscópico. Campeche: Centro EPOMEX-Universidad Autónoma de Campeche.

Jiménez-Badillo L. 2010. Geographic information system: a tool to manage the octopus fishery in the Veracruz Reef System National Park, Mexico. GIS/Spatial Analyses in Fishery and Aquatic Sciences 4: 319-328.

Jiménez BML. 2013. Manejo de la pesquería de pulpo en el estado de Veracruz con énfasis en el Sistema Arrecifal Veracruzano. In: Aldana AD, Enriquez DM, Elías V, eds. Manejo de los recursos pesqueros de la cuenca del Golfo de México y del Mar Caribe. Veracruz: La Ciencia en Veracruz. Universidad Veracruzana, 229-236.

Kaneko N, Kubodera T, Iguchis A. 2011. Taxonomic Study of Shallow-Water Octopuses (Cephalopoda: Octopodidae) in Japan and Adjacent Waters using Mitochondrial Genes with Perspectives on Octopus DNA Barcoding. Malacologia 54: 97-108 DOI 10.4002/040.054.0102.

Kumar S, Stecher G, Tamura K. 2016. MEGA7: Molecular evolutionary genetics analysis Version 7.0 for Bigger Datasets. Molecular Biology and Evolution 28: 2731-2739 DOI 10.1093/molbev/msw054.

Leite TS, Haimovici M, Molina W, Warnke K. 2008. Morphological and genetic description of Octopus insularis, a new cryptic species in the Octopus vulgaris complex (Cephalopoda: Octopodidae) from the 
678

679

680

681

682

683

684

685

686

687

688

689

690

691

692

693

694

695

696

697

698

699

700

701

702

703

tropical southwestern Atlantic. Journal of Molluscan Studies 74: 63-74 DOI 10.1093/mollus/eym050.

Leite TS, Mather JA. 2008. A new approach to octopuses' body pattern analysis: A framework for taxonomy and behavioral studies. American Malacological Bulletin 24: 31-41 DOI 10.4003/0740-2783-24.1.31.

Lima FD, Berbel-Filho WM, Leite TS, Rosas C, Lima SM. 2017. Occurrence of Octopus insularis Leite and Haimovici, 2008 in the Tropical Northwestern Atlantic and implications of species misidentification to octopus fisheries management. Marine Biodiversity 47: 723-734 DOI 10.1007/s12526-017-0638-y.

Lima FD, Leite TS, Haimovici M, Lins Oliveira JE. 2014. Gonadal development and reproductive strategies of the tropical octopus (Octopus insularis) in northeast Brazil. Hydrobiologia 725: 7-21 DOI 10.1007/s10750-013-1718-z.

Mangold K. 1998. The Octopodinae from the Eastern Atlantic Ocean and the Mediterranean Sea. In: Voss NA, Vecchione M, Toll RB, eds. Systematics and biogeography of cephalopods. II. Washington, DC: Smithsonian Contributions to Zoology, 521-547.

Mateos-Jasso A, Zavala-Hidalgo J, Romero-Centeno R, Allende-Arandía ME. 2012. Variability of the thermohaline structure in the northern Veracruz Coral Reef System, Mexico. Continental Shelf Research 50: 30-40 DOI 10.1016/j.csr.2012.10.001.

Méndez Aguilar FD, Jiménez Badillo ML, Arenas Fuentes V. 2007. Cultivo experimental del pulpo (Octopus vulgaris, Cuvier, 1797) en Veracruz y su aplicación al Parque Nacional Sistema Arrecifal Veracruzano: investigaciones actuales. In: Granados Barba A, Abarca Arenas LG, Vargas Hernández JM, eds. Investigaciones Científicas en el Sistema Arrecifal Veracruzano. Campeche: Universidad Autónoma de Campeche, 257-274.

Norman MD. 1992. Four new octopus species of the Octopus macropus group (Cephalopoda: Octopodidade) from the Great Barrier Reef, Australia. Memoirs of the Museum of Victoria 53: $267-308$. 
704 Norman MD, Finn JK. 2016. World octopod fisheries. In: Jereb P, Roper CFE, Norman MD, Finn

705

706

707

708

709

710

711

712

713

714

715

716

717

718

719

720

721

722

723

724

725

726

727

728

729

730

JK, eds. Cephalopods of the world. An annotated and illustrated catalogue of cephalopod species known to date. Volume 3. Octopods and Vampire Squids. Rome: FAO Species Catalogue for Fishery Purposes, 9-14.

Norman MD, Finn JK, Hochberg FG. 2016. Family Octopodidae. In: Jereb P, Roper CFE, Norman MD, Finn JK, eds. Cephalopods of the world. An annotated and illustrated catalogue of cephalopod species known to date. Volume 3. Octopods and Vampire Squids. Rome: FAO Species Catalogue for Fishery Purposes, 36-215.

Norman MD, Hochberg FG, Lu CC. 1997. Mollusca Cephalopoda: mid-depth octopuses (200$1000 \mathrm{~m}$ ) of the Banda and Arafura Seas (Octopodidae and Alloposidae). Résultats des Campagnes MUSORSTOM 16: 357-383.

Norman MD, Hochberg FG. 2005. The current state of octopus taxonomy. Phuket Marine Biological Centre Research Bulletin 66: 127-154.

Otero J, González AF, Sieiro MP, Guerra A. 2007. Reproductive cycle and energy allocation of Octopus vulgaris in Galician waters, NE Atlantic. Fisheries Research 85: 122-129 DOI 10.1016/j.fishres.2007.01.007.

Pliego-Cárdenas R, Hochberg FG, García de León FJ, Barriga-Sosa IDLA. 2014. Close genetic relationships between two American Octopuses: Octopus hubbsorum Berry, 1953 and $O$. mimus Gould, 1852. Journal of Shellfish Research, 33: 1-11 DOI 10.2983/035.033.0128.

Pomiankowski A, Moller A. 1995. A resolution of the lek paradox. Proceedings of the Royal Society of London B: Biological Sciences 260: 21-29 DOI 10.1098/rspb.1995.0054.

Rambaut A, Suchard MA, Xie D, Drummond AJ. 2014. Tracer v1.6. Available at: http://beast.bio.ed.ac.uk/Tracer

Ronquist F, Huelsenbeck JP. 2003. MrBayes3: Bayesian phylogenetic inference under mixed models. Bioinformatics 19:1572-1574 DOI 10.1093/bioinformatics/btg180.

Roper CFE, Gutierrez A, Vecchione M. 2015. Paralarval octopods of the Florida Current. Journal of Natural History, 49: 1281-1304 DOI 10.1080/00222933.2013.802046. 
731 Roper CFE, Voss GL. 1983. Guidelines for taxonomic description of cephalopod species. In:

732

733

734

735

736

737

738

739

740

741

742

743

744

745

746

747

748

749

750

751

752

753

754

755

756

Roper CFE, Lu CC, Hochberg FG, eds. Proceedings of the workshop on the biology and resource potential of cephalopods. Melbourne: National Museum of Victoria, 48-64.

Rosas C, Gallardo P, Mascaró M, Caamal-Monsreal C, Pascual C. 2014. Octopus maya. In:

Iglesias J, Fuentes L, Villanueva R, eds. Cephalopod culture. Amsterdam: Springer, 383396.

Roura A, Álvarez-Salgado XA, González AF, Gregori M, Rosón G, Otero J, Guerra A. 2016. Life strategies of cephalopod paralarvae in a coastal upwelling system (NW Iberian Peninsula): insights from zooplankton community and spatio-temporal analyses. Fisheries oceanography 25: 241-258 DOI 10.1111/fog.12151.

Salas-Monreal D, Salas-de-León DA, Monreal-Gómez MA, Riverón-Enzástiga ML. 2009. Current rectification in a tropical coral reef system. Coral Reefs 28: 871 DOI 10.1007/s00338-009-0521-9.

Sales JBL, Rego PS, Hilsdorf AWS, Moreira AA, Haimovici M, Tomás AR, Baptista BB, Marinho RA, Markaida U, Schneider H, Sampaio I. 2013. Phylogeographical features of Octopus vulgaris and Octopus insularis in the Southeastern Atlantic based on the analysis of mitochondrial markers. Journal of Shellfish Research 32: 325-339 DOI 10.2983/035.032.0211.

Simon C, Franke A, Martin AP. 1991. The polymerase chain reaction: DNA extraction and amplification. In: Gewitt GM, Johnston AWB, Young JPW, eds. Molecular Techniques in Taxonomy. New York: Springer Verlag, 329-355.

Strugnell J. 2004. The Molecular evolutionary history of the class Cephalopoda (Phylum Mollusca). D. Phil. Thesis. University of Oxford.

Strugnell JM, Collins MA, Allcock AL. 2008. Molecular evolutionary relationships of the octopodid genus Thaumeledone (Cephalopoda: Octopodidae) from the Southern Ocean. Antarctic Science 20: 245-251 DOI 10.1017/S0954102008001132. 
757 Strugnell JM, Norman MD, Vecchione M, Guzik M, Allcock AL. 2014. The ink sac clouds

758

759

760

761

762

763

764

765

766

767

768

769

770

771

772

773

774

775

776

777

778

779

780

781

782

783 octopod evolutionary history. Hydrobiologia 725: 215-235 DOI 10.1007/s10750-0131517-6.

Takumiya M, Kobayashi M, Tsuneki K, Furuya H. 2005. Phylogenetic Relationships among Major Species of Japanese Coleoid Cephalopods (Mollusca: Cephalopoda) Using Three Mitochondrial DNA Sequences. Zoological Science 22: 147-155 DOI 10.2108/zsj.22.147.

Tamura K, Nei M. 1993. Estimation of the number of nucleotide substitutions in the control region of mitochondrial DNA in humans and chimpanzees. Molecular Biology and Evolution 10: 512-526 DOI 10.1093/oxfordjournals.molbev.a040023.

Teske PR, Oosthuizen A, Papadopoulos I, Barker NP. 2007. Phylogeographic structure of Octopus vulgaris in South Africa revisited: identification of a second lineage near Durban harbor. Marine Biology 151: 2119-2122 DOI 10.1007/s00227-007-0644-x.

Vecchione M, Collette BB. 1996. The central role of systematics in marine biodiversity issues. Oceanography, 9: 44-49.

Voss GL, Solís-Ramírez M. 1966. Octopus maya, a new species from the Bay of Campeche, Mexico. Bulletin of Marine Sciences 16: 615-625.

Voss GL, Toll RB. 1998. The systematic and nomenclatural status of the Octopodinae described from the Western Atlantic Ocean. In: Voss NA, Vecchione M, Toll RB, eds. Systematics and biogeography of cephalopods, II. Washington, DC: Smithsonian Contributions to Zoology, 457-474.

Wall AR, Campo D, Wetzer R. 2014. Genetic utility of natural history museum specimens: endangered fairy shrimp (Branchiopoda, Anostraca). ZooKeys 457: 1-14 DOI 10.3897/zookeys.457.6822.

Ward RD. 2000. Genetics in fisheries management. Hydrobiologia 420: 191-201 DOI 10.1023/A:1003928327503.

Warnke K, Söller R, Blohm D, Saint-Paul U. 2004. A new look at geographic and phylogenetic relationships within the species group surrounding Octopus vulgaris (Mollusca, 
784 Cephalopoda): Indications of very wide distribution from mitochondrial DNA sequences.

785 Journal of Zoological Systematics and Evolutionary Research 42: 306-312 DOI

786 10.1111/j.1439-0469.2004.00277.x. 


\section{Figure 1}

Map of the Veracruz Reef System, southwestern Gulf of Mexico.

Black triangles indicate collecting sites (specimens were collected in the reef lagoon and fore-reef). Degrees are in decimal notation.

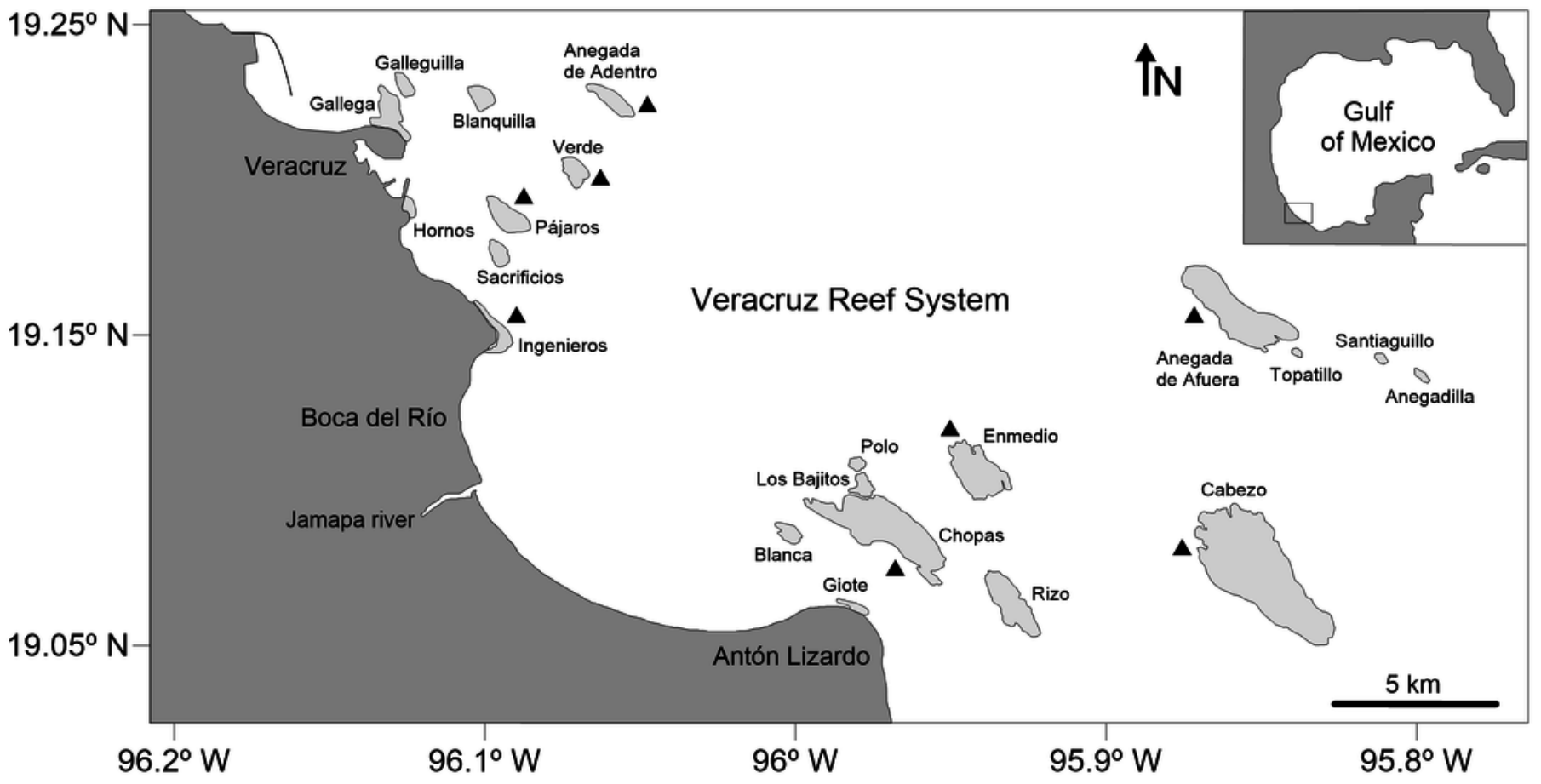


Figure 2

Veracruz Reef System common octopus.

A. Dorsal view of a $164 \mathrm{~mm}$ ML male. B. W-shaped funnel organ of a $122 \mathrm{~mm} \mathrm{ML}$ male. C. Ligula and calamus of a $101 \mathrm{~mm}$ ML male. D. Pair of stylets of a $124 \mathrm{~mm}$ ML male. E. Ventral view of a male specimen showing the position of enlarged suckers in arms II and III of mature males. Scale bars: $\mathbf{A}=5 \mathrm{~cm} ; \mathbf{B}=1 \mathrm{~cm} ; \mathbf{C}=2 \mathrm{~mm} ; \mathbf{D}=1 \mathrm{~cm} ; \mathbf{E}=2 \mathrm{~cm}$. 


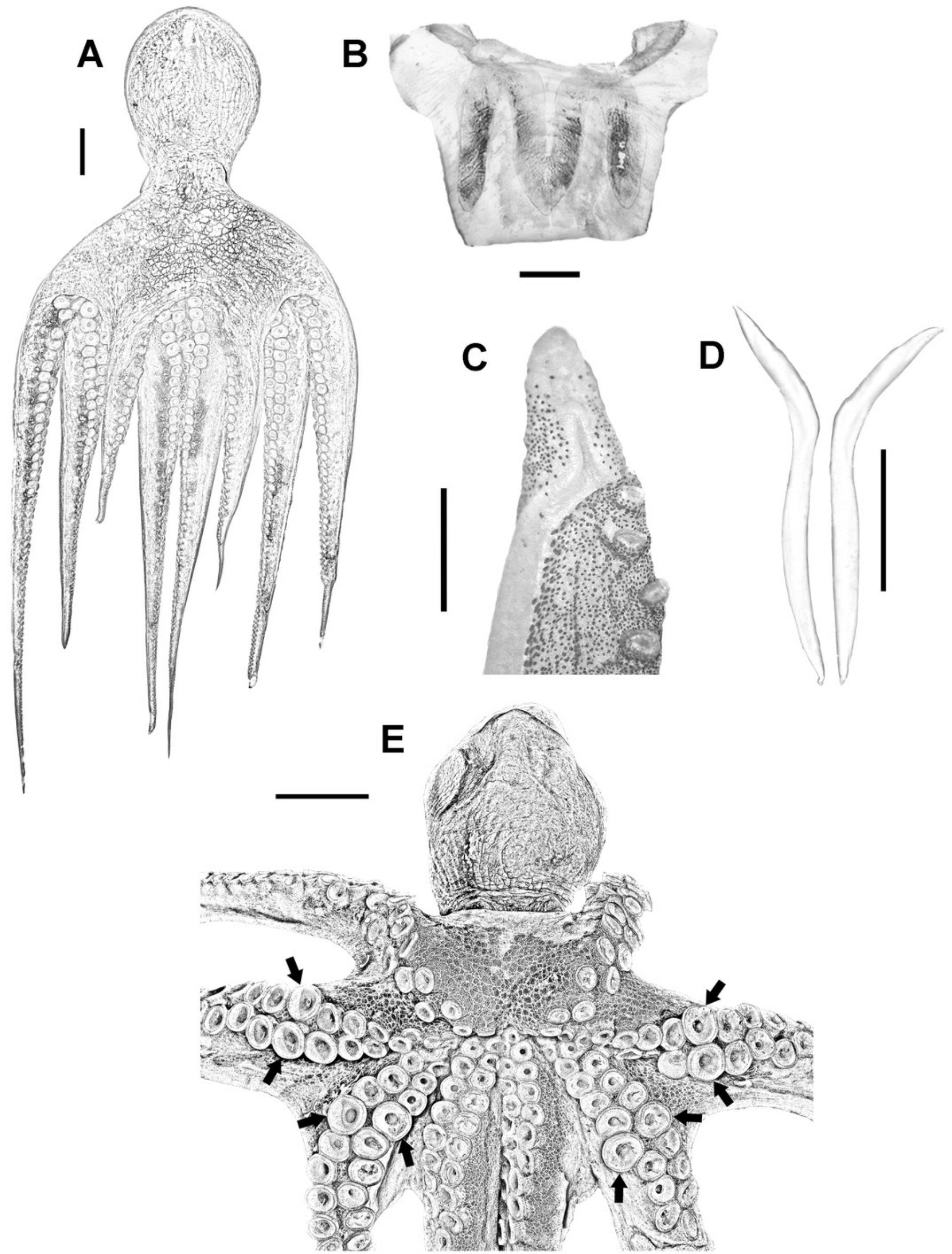




\section{Figure 3}

Digestive system of the VRS common octopus.

A. Digestive system of a $164 \mathrm{~mm} \mathrm{ML} \mathrm{male.} \mathrm{B.} \mathrm{Radula} \mathrm{of} \mathrm{a} 124 \mathrm{~mm} \mathrm{ML} \mathrm{male} \mathrm{showing} \mathrm{A}_{3}$ seriation. C. Upper beak of a $124 \mathrm{~mm}$ ML male. D. Lower beak of a $124 \mathrm{~mm}$ ML male. E. Radula. Abbreviations: Asg, Anterior salivary glands; Bm, Buccal mass; Ca, Caecum; Cr, Crop; Dg, Digestive gland; In, Intestine; Is, Ink sac; Psg, Posterior salivary glands; Sd, Salivary duct; St, Stomach. E. Radula. Scale bars: $\mathbf{A}=2 \mathrm{~cm} ; \mathbf{B}=50 \mu \mathrm{m} ; \mathbf{C}=5 \mathrm{~mm} ; \mathbf{D}=5 \mathrm{~mm} ; \mathbf{E}=250 \mu \mathrm{m}$. 


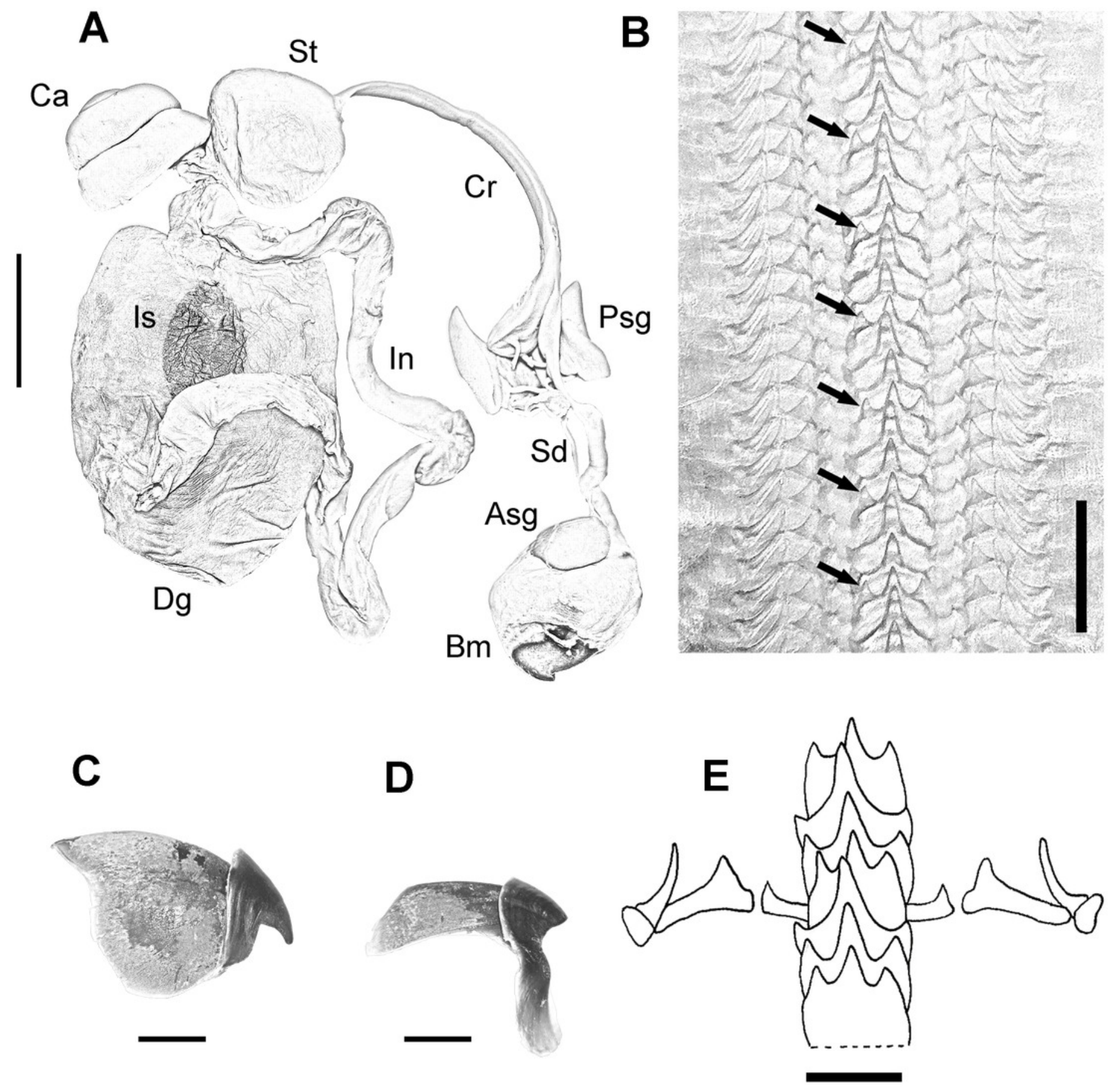


Figure 4

Reproductive system of the VRS common octopus.

A. Reproductive system of a $156 \mathrm{~mm}$ ML female. B. Reproductive system of a $159 \mathrm{~mm} \mathrm{ML}$ male. C. Egg of a $113 \mathrm{~mm}$ ML female. D. Spermatophore of a $159 \mathrm{~mm}$ ML male.

Abbreviations: Acsg, Accesory spermatophoric gland; Do, Distal oviduct; Og, Oviductal gland;

Ov, Ovary; Po, Proximal oviduct; Sc, Spermatophore storage sac; Sg, Spermatophoric gland;

To, Terminal organ; Ts, Testis; Vd, Vas deferens. Scale bars: $\mathbf{A}=10 \mathrm{~mm} ; \mathbf{B}=10 \mathrm{~mm} ; \mathbf{C}=1$ $\mathrm{mm} ; \mathbf{D}=5 \mathrm{~mm}$. 


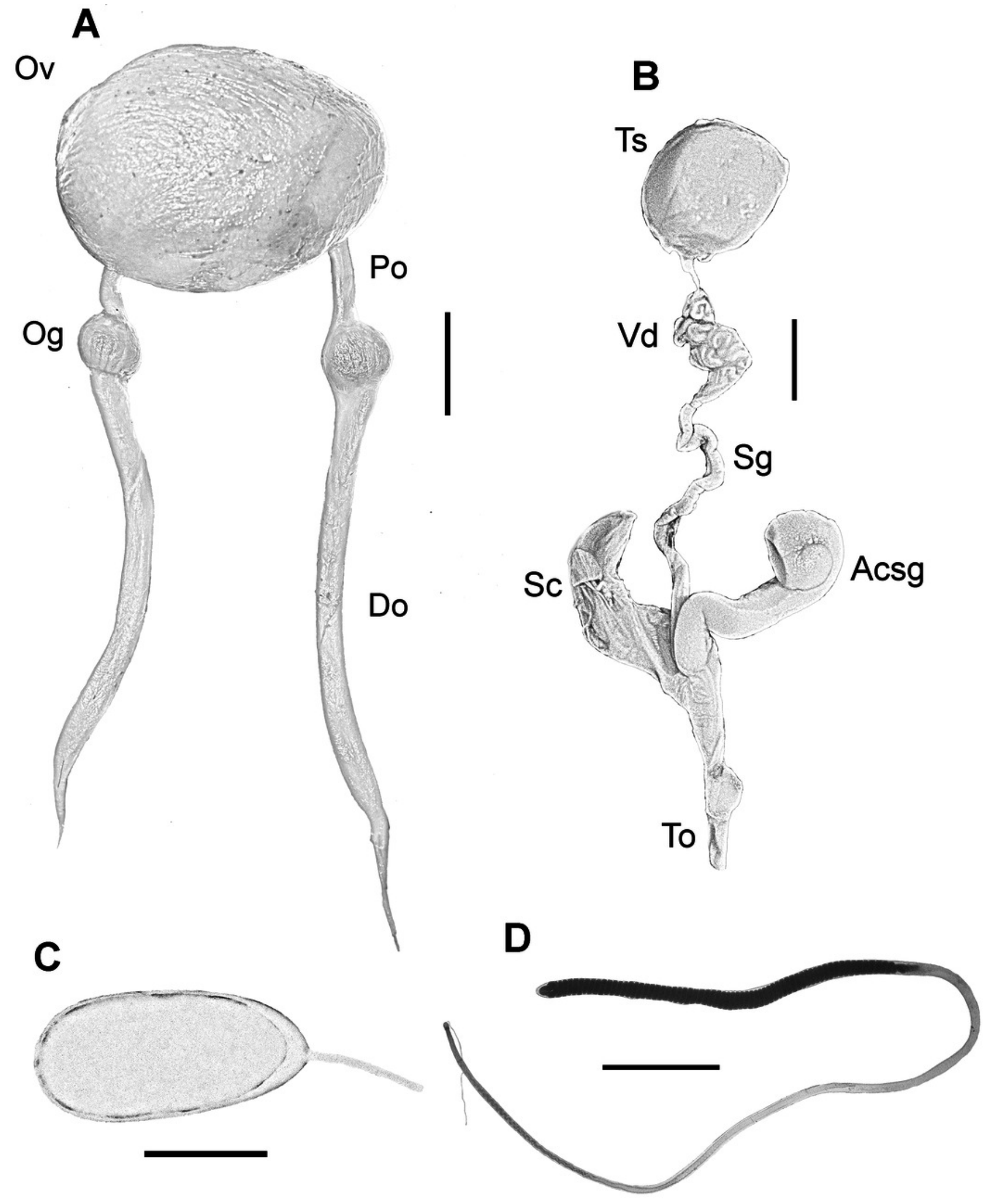




\section{Figure 5}

Skin and colour patterns of the VRS common octopus.

A. Living specimen hidden in a den showing a characteristic red/white reticulate pattern in the arms and alternating light/dark bars around the eye. One large cirrus and some other small ones can also be observed over the eye. Photograph taken at Enmedio reef, Veracruz.

B. Fresh specimen showing the blue-green colour around the eye (Photo credits A, B: Roberto González-Gómez). 

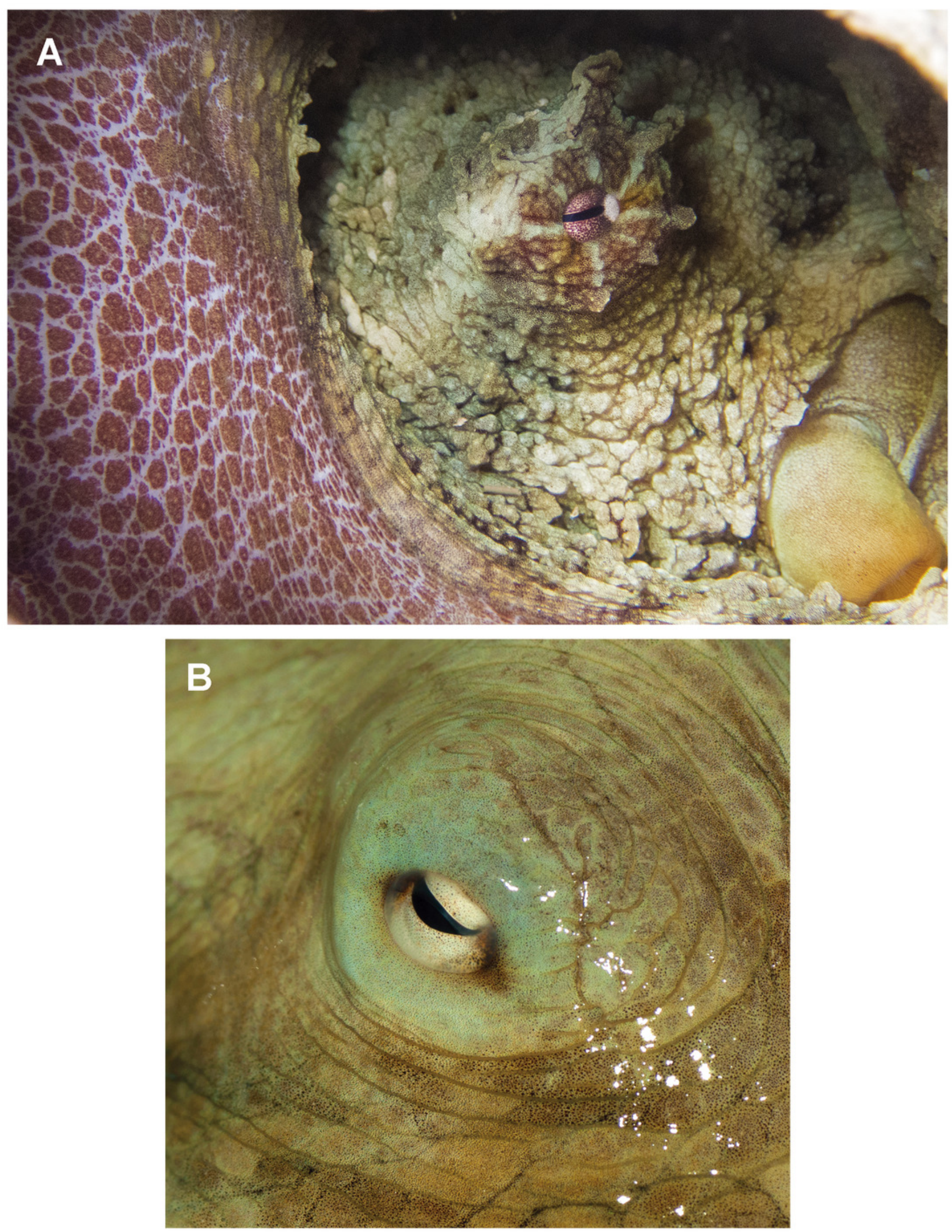


\section{Figure 6}

Principal coordinate ordination (PCO) plot of morphological traits.

Bi-plot showing differences on morphological traits among octopod taxa with vector overlay from Pearson's correlation '0.6. The blue circle represents a maximal vector. Each symbol represents a specimen. HcAl, hectocotylized arm index; HASC, hectocotylized arm sucker count; eSDI, enlarged sucker diameter index; WDI, web depth index; HWI, head width index; TOLI, terminal organ length index; MWI, mantle width index; FLI, funnel length index; CLI, calamus length index; LLI, ligula length index.

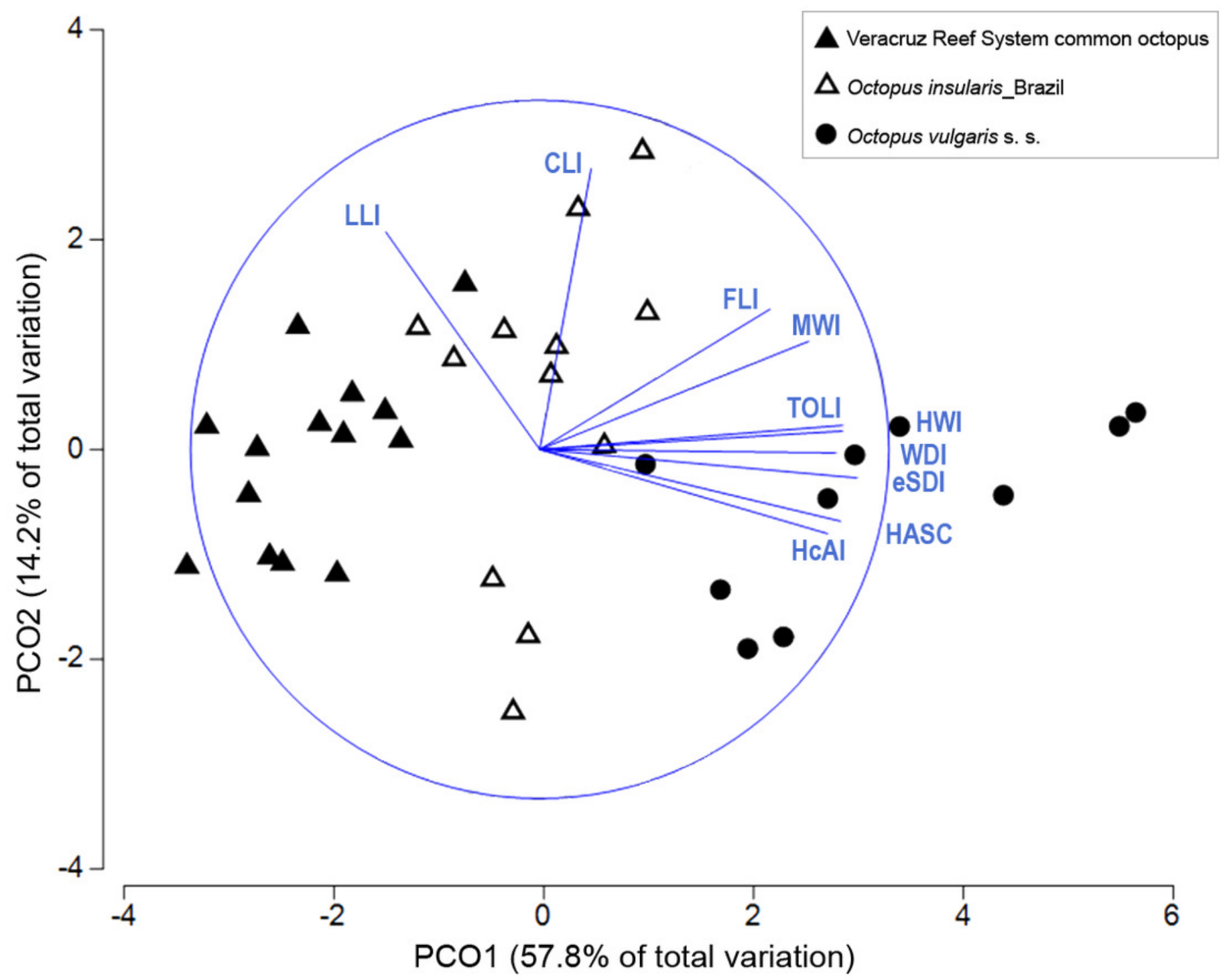


Figure 7

Bayesian phylogenetic tree based on COI sequences.

Shows the VRS common octopus (O. insularis) clade and the $O$. vulgaris type II clade. Each node is labeled with its posterior probability. 


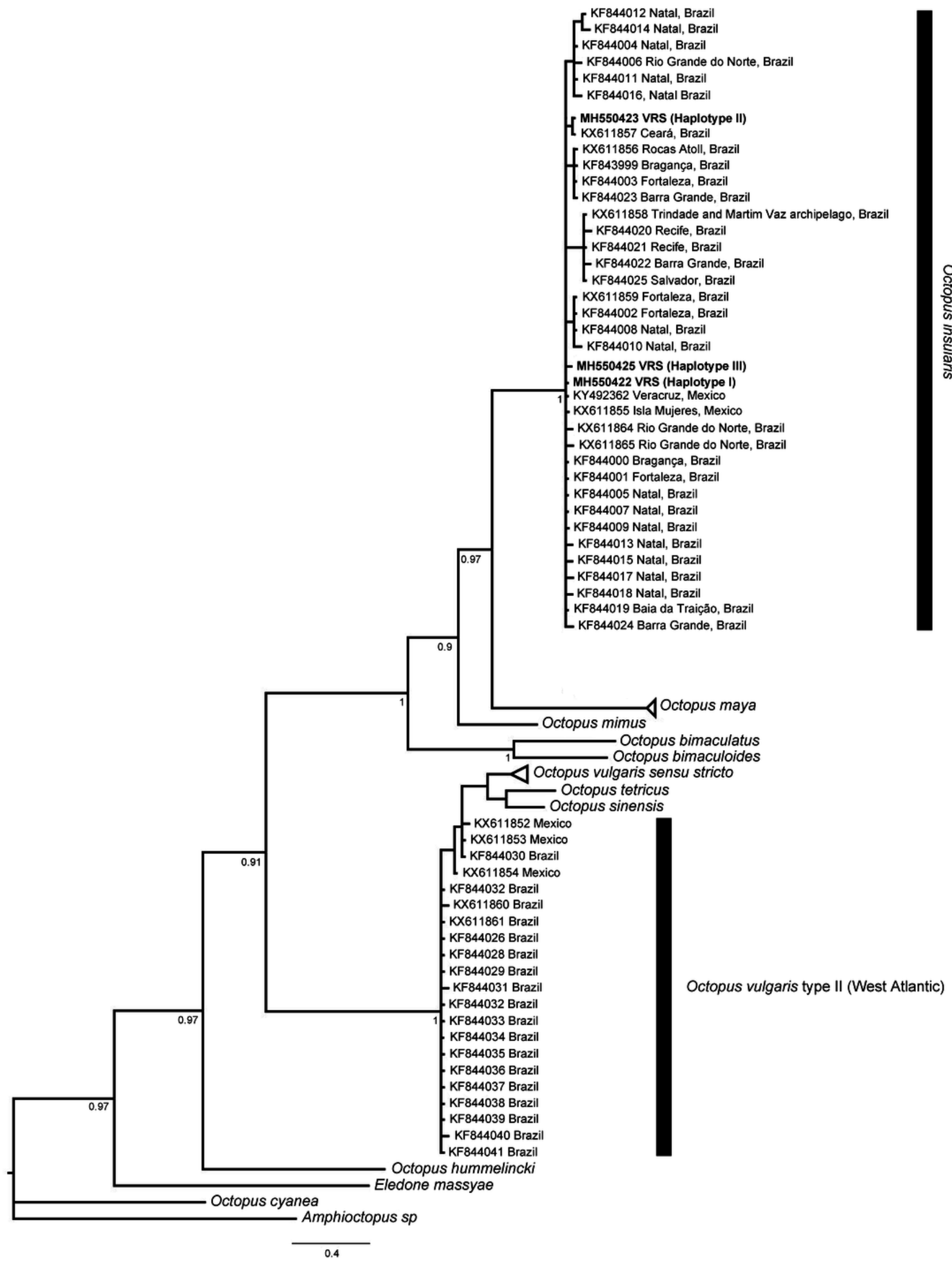




\section{Figure 8}

Bayesian phylogenetic tree based on r16S sequences.

Shows the VRS common octopus (Octopus insularis) clade and the $O$. vulgaris type II clade.

Each node is labeled with its posterior probability. 


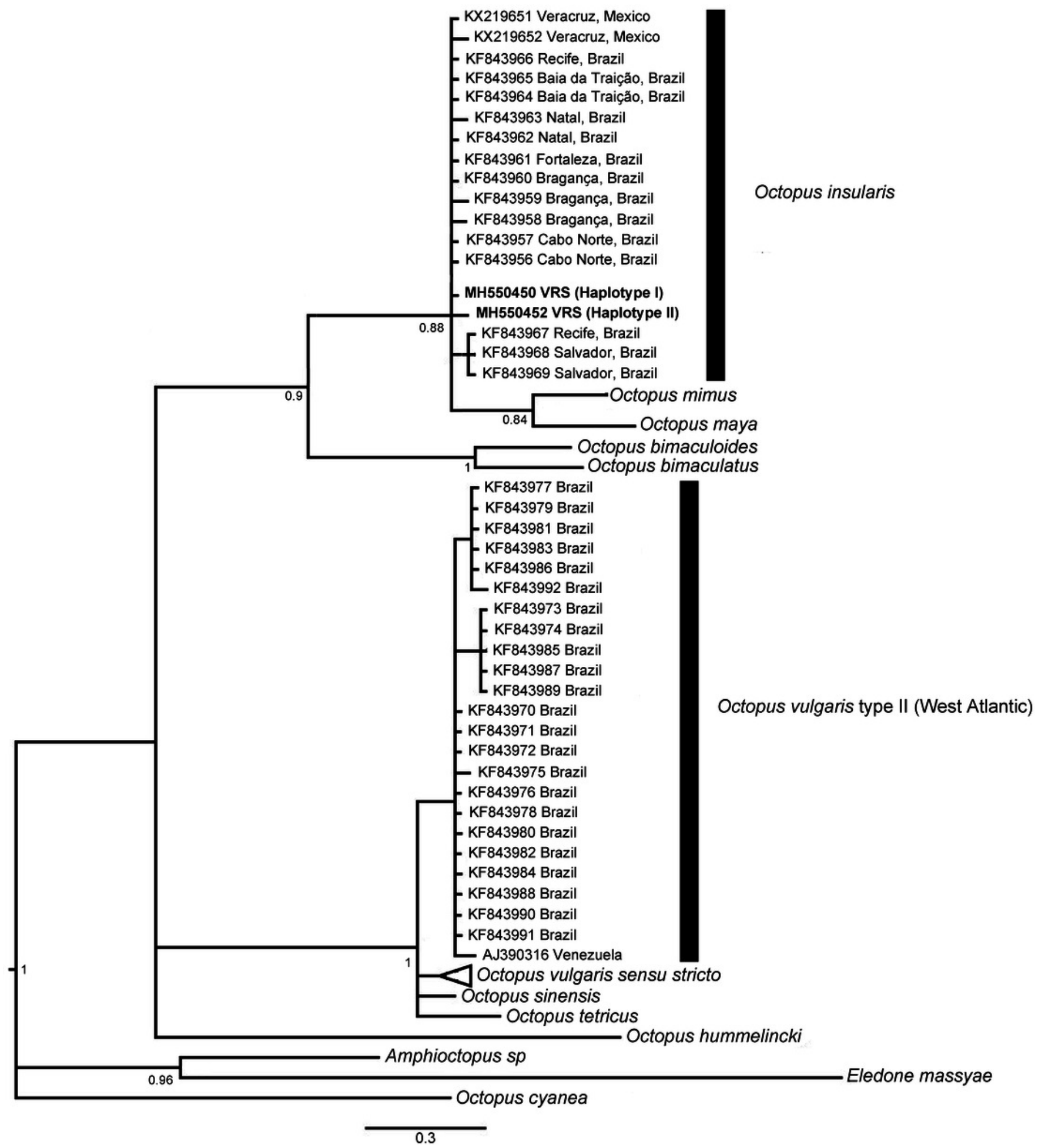




\section{Figure 9}

In situ photographs of octopus specimens.

A. Octopus insularis from Brazil; B. O. insularis from Veracruz, Mexico. C. O. cf. insularis from Puerto Morelos Reef National Park, Quintana Roo, Mexico (Photo credits A: Tatiana S. Leite; B, C: Roberto González-Gómez). 

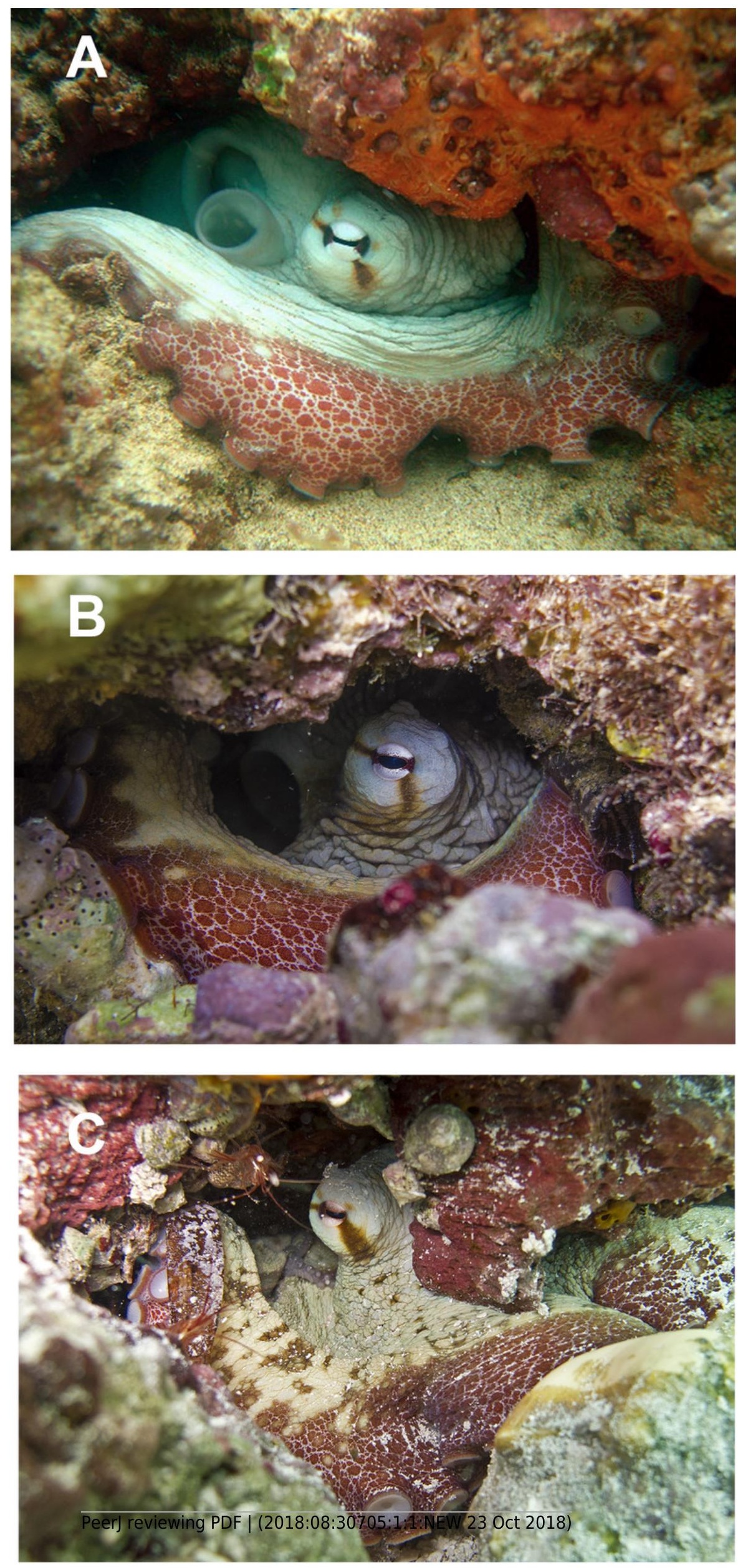


\section{Table $\mathbf{1}$ (on next page)}

Morphological measurements and counts of the VRS common octopus. 


\begin{tabular}{lcccccc}
\hline \multirow{2}{*}{ Parameter } & \multicolumn{3}{c}{ Males $(\mathrm{n}=14)$} & \multicolumn{3}{c}{ Females $(\mathrm{n}=4)$} \\
\cline { 2 - 7 } & 113 & Mean & Max & Min & Mean & Max \\
\hline Total weight & 375 & 50.2 & 1811 & 595 & 1014.0 & 1326 \\
Total length & 101 & 130.4 & 696 & 515 & 564.3 & 630 \\
Mantle length (dorsal) & 53.2 & 75.9 & 110.0 & 77.6 & 86.1 & 90.8 \\
Mantle width & 33.1 & 46.1 & 65.3 & 32.6 & 47.7 & 61.9 \\
Head width & 2.6 & 4.2 & 5.8 & - & - & - \\
Ligula length & 1.1 & 2.1 & 3.2 & - & - & - \\
Calamus length & 103 & 122 & 146 & - & - & - \\
Hectocotylized arm sucker count & 7.2 & 10.9 & 16.7 & 9.5 & 11.1 & 12.2 \\
Normal sucker diameter & 9.1 & 14.1 & 19.8 & - & - & - \\
Enlarged sucker diameter & 10.8 & 14.1 & 18.0 & - & - & - \\
Terminal organ length & & & & & \\
Arm Length & $243 / 292$ & $345 / 361.5$ & $421 / 488$ & $280 / 278$ & $336.3 / 379.5$ & $416 / 481$ \\
1 & $242 / 253$ & $384.7 / 354.8$ & $527 / 501$ & $389 / 175$ & $453.7 / 360.5$ & $536 / 484$ \\
2 & $257 / 293$ & $342.1 / 351.6$ & $446 / 388$ & $281 / 412$ & $363 / 425.5$ & $445 / 439$ \\
3 & $284 / 256$ & $388.1 / 378.1$ & $590 / 539$ & $406 / 275$ & $456 / 413$ & $512 / 502$ \\
4 & & & & & & \\
Arm sucker count & $162 / 178$ & $192.5 / 201$ & $219 / 228$ & $103 / 125$ & $167.6 / 182.5$ & $235 / 240$ \\
1 & $162 / 170$ & $201.7 / 195.6$ & $227 / 222$ & $158 / 124$ & $215.5 / 192.3$ & $249 / 232$ \\
2 & $103 / 145$ & $122 / 190$ & $146 / 225$ & $148 / 200$ & $161.5 / 201$ & $175 / 202$ \\
3 & $113 / 175$ & $211.3 / 214.4$ & $257 / 267$ & $208 / 160$ & $225.5 / 209.3$ & $263 / 249$ \\
4 & 15.1 & 21.2 & 28.1 & 16.8 & 20.7 & 25.3 \\
Arm width & & & & & & \\
Web depth & 37.8 & 53.7 & 74.9 & 36.7 & 51.8 & 64.3 \\
A & 52.3 & 69.6 & 96.4 & 55.8 & 74.1 & 86.4 \\
B & 62.9 & 85.7 & 118.6 & 88.1 & 92.5 & 99.0 \\
C & 62.4 & 86.7 & 128.0 & 86.2 & 92.6 & 98.4 \\
D & & & & & &
\end{tabular}


E

Funnel length

Eye lens diameter

Spermatophore length

Spermatophore width

Pallial aperture

Gill count
40.6

30.8

5.2

33.8

0.6

35.3
69.9

41.0

7.3

46.4

0.7

52.3

$\begin{array}{cc}104.0 & 70.7 \\ 55.5 & 36.4 \\ 10.1 & 5.4 \\ 57.2 & - \\ 0.9 & - \\ 77.5 & 57.9 \\ 11 & 9\end{array}$

74.8

84.5

50.1

8.8

$-$

69.8

10

2

3 Note: values of arm length and arm sucker count are: right arm/left arm. Measurements are in mm and weight in g. 
Table 2 (on next page)

Morphological indices of the VRS common octopus. 


\begin{tabular}{lccc|ccc}
\hline \multirow{2}{*}{ Parameter } & \multicolumn{3}{c|}{ Males $(\mathrm{n}=14)$} & \multicolumn{3}{c}{ Females $(\mathrm{n}=4)$} \\
\cline { 2 - 7 } & Min & Mean & Max & Min & Mean & Max \\
\hline Head width index & 27.67 & 35.80 & 50.13 & 28.80 & 34.33 & 43.90 \\
Mantle width index & 45.85 & 58.14 & 74.24 & 55.43 & 63.49 & 80.21 \\
Ligula length index & 0.92 & 1.25 & 1.65 & - & - & - \\
Calamus length index & 40.79 & 49.18 & 58.56 & - & - & - \\
Normal sucker diameter index & 7.05 & 8.32 & 10.42 & 7.43 & 8.04 & 8.58 \\
Enlarged sucker diameter index & 8.87 & 10.64 & 13.75 & - & - & - \\
Mantle arm index & 26.60 & 31.10 & 35.02 & 24.34 & 28.78 & 31.75 \\
Arm length index & 77.53 & 82.73 & 87.22 & 83.30 & 84.91 & 85.64 \\
Opposite arm index & 77.06 & 85.65 & 90.75 & - & - & - \\
Arm width index & 12.82 & 16.40 & 23.15 & 13.44 & 15.06 & 17.94 \\
Hectocotylized arm index & 229.56 & 265.21 & 306.88 & - & - & - \\
Funnel length index & 26.79 & 31.48 & 37.00 & 31.91 & 39.16 & 49.47 \\
Pallial aperture index & 33.45 & 40.07 & 50.48 & 39.04 & 46.26 & 61.66 \\
Eye lens diameter index & 0.04 & 0.06 & 0.07 & 0.04 & 0.06 & 0.08 \\
Web depth index & 16.35 & 21.25 & 24.91 & 18.47 & 19.79 & 21.52 \\
Terminal organ length index & 7.51 & 11.28 & 13.29 & - & - & - \\
Spermatophore length index & 28.06 & 32.43 & 38.68 & - & - & - \\
\hline
\end{tabular}




\section{Table 3(on next page)}

Comparison of morphological traits between octopus taxa.

Contribution of morphological traits to the average squared Euclidean distance between the VRS common octopus, O. insularis from Brazil and O. vulgaris s. s. (see Methods for abbreviations of morphological traits). 


\begin{tabular}{cccc}
\hline \multicolumn{4}{c}{ Group VRS common octopus \& Octopus vulgaris sensu stricto } \\
\multicolumn{4}{c}{ Average squared distance $=37.45$} \\
Trait & Average squared distance & Contribution \% & Cumulative \% \\
HASC & 4.99 & 13.33 & 13.33 \\
TOLI & 4.97 & 13.27 & 26.60 \\
eSDI & 4.8 & 12.82 & 39.42 \\
WDI & 4.63 & 12.37 & 51.79 \\
HWI & 4.3 & 11.49 & 63.28 \\
HcAl & 3.97 & 10.60 & 73.89 \\
\hline
\end{tabular}

Group VRS common octopus \& Octopus insularis from Brazil

Average squared distance $=15.50$

$\begin{array}{cccc}\text { Trait } & \text { Average squared distance } & \text { Contribution \% } & \text { Cumulative \% } \\ \text { WDI } & 3.17 & 20.47 & 20.47 \\ \text { MWI } & 2.62 & 16.90 & 37.37 \\ \text { CLI } & 2.45 & 15.80 & 53.16 \\ \text { HWI } & 2.14 & 13.77 & 66.94 \\ \text { LLI } & 2.03 & 13.08 & 80.02\end{array}$

Group Octopus insularis from Brazil \& Octopus vulgaris sensu stricto Average squared distance $=24.42$

Trait Average squared distance Contribution \% Cumulative \%

$\begin{array}{cccc}\text { HcAl } & 4.75 & 19.45 & 19.45 \\ \text { eSDI } & 3.99 & 16.34 & 35.79 \\ \text { HASC } & 3.55 & 14.54 & 50.33 \\ \text { CLI } & 2.72 & 11.15 & 61.49 \\ \text { FLI } & 2.62 & 10.69 & 72.17 \\ \text { LLI } & 2.19 & 8.95 & 81.12\end{array}$

2 Notes: Morphological traits are listed in decreasing order of Contribution $\%$. Cumulative $\%$ does 3 not reach $100 \%$ in order to facilitate interpretation. 


\section{Table 4(on next page)}

\section{Genetic distances.}

Tamura-Nei average genetic distances (\%) between the specimens from the Veracruz Reef System and related octopus species for COI, COIII, r16S and rhodopsin gene regions. GenBank accession numbers are provided for comparison. 


\begin{tabular}{|c|c|c|c|c|c|}
\hline \multirow[b]{2}{*}{ Taxa } & \multicolumn{4}{|c|}{ Veracruz Reef System common octopus } & \multirow[b]{2}{*}{ Reference } \\
\hline & COI & COIII & r16S & Rhodopsin & \\
\hline $\begin{array}{l}\text { Octopus insularis } \\
\text { VRS. }\end{array}$ & $0.0-0.4$ & 0 & $0.0-0.3$ & 0 & This study \\
\hline $\begin{array}{l}\text { Octopus insularis } \\
\text { Isla Mujeres, MX }\end{array}$ & $\begin{array}{c}0.0-0.2 \\
(\mathrm{KX} 611855)\end{array}$ & NA & NA & NA & Lima et al. (2017) \\
\hline $\begin{array}{l}\text { Octopus insularis } \\
\text { Brazil }\end{array}$ & $\begin{array}{l}0-0-0.2 \\
(K F 843999- \\
\text { KF844025) }\end{array}$ & $\begin{array}{c}0 \\
(\text { AJ012123) }\end{array}$ & $\begin{array}{l}0.0-0.6 \\
(\mathrm{KF} 843956- \\
\text { KF843969) }\end{array}$ & NA & $\begin{array}{c}\text { Sales et al. (2013) } \\
\text { Warnke et al. (2004) }\end{array}$ \\
\hline $\begin{array}{l}\text { Octopus maya } \\
\text { Mexico }\end{array}$ & $\begin{array}{c}0.8-0.9 \\
(\mathrm{~K} X 611862 \\
\mathrm{KX} 611863)\end{array}$ & $\begin{array}{c}5.6 \\
(K \times 219650)\end{array}$ & $\begin{array}{c}3.8-3.9 \\
(K X 219653)\end{array}$ & NA & $\begin{array}{l}\text { Flores-Valle et al. (2018) } \\
\quad \text { Lima et al. (2017) }\end{array}$ \\
\hline $\begin{array}{l}\text { Octopus mimus } \\
\text { Chile /MX }\end{array}$ & $\begin{array}{c}0.6 \\
\text { (GU355926) }\end{array}$ & $\begin{array}{c}5.3 \\
(\mathrm{AJ} 012128)\end{array}$ & $\begin{array}{c}4.7-5.1 \\
(\mathrm{AJ} 390318)\end{array}$ & $\begin{array}{c}0.5 \\
(\text { KT335848) }\end{array}$ & $\begin{array}{l}\text { Acosta-Jofré et al. (2012) } \\
\text { Warnke et al. (2004) }\end{array}$ \\
\hline $\begin{array}{c}\text { Octopus } \\
\text { bimaculatus } \mathrm{MX}\end{array}$ & $\begin{array}{l}11.2-11.5 \\
(\mathrm{KT} 335828)\end{array}$ & $\begin{array}{c}5.5 \\
(X 83100)\end{array}$ & $\begin{array}{c}6.3 \\
(\mathrm{KT} 335834)\end{array}$ & $\begin{array}{c}1.7 \\
(\mathrm{KT} 335846)\end{array}$ & $\begin{array}{l}\text { Flores-Valle et al. (2018) } \\
\text { Barriga-Sosa et al. (1995) }\end{array}$ \\
\hline $\begin{array}{c}\text { Octopus } \\
\text { bimaculoides } \mathrm{MX}\end{array}$ & $\begin{array}{l}11.1-11.4 \\
(\mathrm{KF} 225006)\end{array}$ & $\begin{array}{c}6.3 \\
(K F 225012)\end{array}$ & $\begin{array}{c}6.9 \\
(\mathrm{KF} 373765)\end{array}$ & $\begin{array}{c}1.7 \\
(\mathrm{KT} 335847)\end{array}$ & Pliego-Cárdenas et al. (2014) \\
\hline $\begin{array}{l}\text { Octopus vulgaris } \\
\text { Gulf of Mexico }\end{array}$ & $\begin{array}{l}12.1-12.3 \\
(\mathrm{~K} X 611852- \\
\mathrm{KX} 611854)\end{array}$ & NA & NA & NA & Lima et al. (2017) \\
\hline $\begin{array}{l}\text { Octopus vulgaris } \\
\text { s. s. France }\end{array}$ & $\begin{array}{l}12.8-13.1 \\
(E F 016328)\end{array}$ & $\begin{array}{c}12.6 \\
(\mathrm{AJ} 012121)\end{array}$ & $\begin{array}{c}6.9-7.0 \\
(E F 016336)\end{array}$ & NA & $\begin{array}{l}\text { Allcock et al. (2006) } \\
\text { Warnke et al. (2004) }\end{array}$ \\
\hline $\begin{array}{c}\text { Octopus vulgaris } \\
\text { Brazil }\end{array}$ & $\begin{array}{l}11.8-12.1 \\
(\mathrm{KF} 844026- \\
\text { KF844041) }\end{array}$ & $\begin{array}{c}7.7 \\
(\text { AJ616312) }\end{array}$ & $\begin{array}{c}7.1-7.7 \\
(\mathrm{KF} 843970- \\
\text { KF843991) }\end{array}$ & NA & $\begin{array}{c}\text { Sales et al. (2013) } \\
\text { Warnke et al. (2004) }\end{array}$ \\
\hline $\begin{array}{l}\text { Octopus vulgaris } \\
\text { Japan }\end{array}$ & $\begin{array}{l}12.7-13.0 \\
(\text { AJ616307) }\end{array}$ & $\begin{array}{c}10.5 \\
(\text { AJ616311) }\end{array}$ & $\begin{array}{c}7.3-7.4 \\
(\mathrm{AB} 430546)\end{array}$ & NA & $\begin{array}{c}\text { Kaneko, Kubodera \& Iguchis (2011) } \\
\text { Warnke et al. (2004) }\end{array}$ \\
\hline $\begin{array}{l}\text { Octopus vulgaris } \\
\text { South Africa }\end{array}$ & $\begin{array}{c}12.8-13.1 \\
(\mathrm{HM} 104262)\end{array}$ & $\begin{array}{c}12.6 \\
(\mathrm{AJ} 628241)\end{array}$ & $\begin{array}{c}6.6 \\
(\mathrm{DQ} 683228)\end{array}$ & $\begin{array}{c}2.4 \\
(\mathrm{HM} 104297)\end{array}$ & $\begin{array}{c}\text { Guzik, Norman \& Crozier (2005) } \\
\text { Strugnell et al. (2014) } \\
\text { Teske et al. (2007) }\end{array}$ \\
\hline $\begin{array}{l}\text { Octopus tetricus } \\
\text { Australia }\end{array}$ & $\begin{array}{l}12.4-12.6 \\
(\mathrm{KJ} 605251)\end{array}$ & $\begin{array}{c}11.5 \\
(\text { AJ628237) }\end{array}$ & $\begin{array}{c}7.2-7.3 \\
(\mathrm{KJ} 605231)\end{array}$ & NA & $\begin{array}{c}\text { Amor et al. (2014) } \\
\text { Guzik, Norman \& Crozier (2005) }\end{array}$ \\
\hline $\begin{array}{l}\text { Octopus cyanea } \\
\text { Japan }\end{array}$ & $\begin{array}{c}15.0-15.3 \\
(A B 191280)\end{array}$ & $\begin{array}{c}14.1 \\
(\mathrm{AJ} 628220)\end{array}$ & $\begin{array}{c}9.2-9.3 \\
(\mathrm{GQ} 900721)\end{array}$ & NA & $\begin{array}{c}\text { Guzik, Norman \& Crozier (2005) } \\
\text { Huffard et al. (2010) } \\
\text { Takumiya et al. (2005) }\end{array}$ \\
\hline $\begin{array}{l}\text { Octopus } \\
\text { hummelincki } \\
\text { Brazil }\end{array}$ & $\begin{array}{l}14.2-14.4 \\
(\mathrm{KF} 844044)\end{array}$ & NA & $\begin{array}{c}11.8 \\
(\mathrm{KF} 843996)\end{array}$ & NA & Sales et al. (2013) \\
\hline $\begin{array}{c}\text { Eledone } \\
\text { massyae Brazil }\end{array}$ & $\begin{array}{l}18.9-19.2 \\
(\mathrm{KF} 844046)\end{array}$ & NA & $\begin{array}{c}15.4 \\
(\mathrm{KF} 843998)\end{array}$ & NA & Sales et al. (2013) \\
\hline $\begin{array}{l}\text { Cistopus indicus } \\
\text { West Pacific } \\
\text { Ocean }\end{array}$ & $\begin{array}{c}17.8 \\
(\mathrm{HM} 104258)\end{array}$ & $\begin{array}{c}18.3 \\
(\text { AJ628208) }\end{array}$ & $\begin{array}{c}12.5 \\
(\mathrm{AJ} 252744)\end{array}$ & $\begin{array}{c}3.8 \\
(\mathrm{HM} 104291)\end{array}$ & $\begin{array}{l}\text { Guzik, Norman \& Crozier (2005) } \\
\text { Strugnell et al. (2014) }\end{array}$ \\
\hline $\begin{array}{l}\text { Amphioctopus } \\
\text { sp. Brazil }\end{array}$ & $\begin{array}{l}18.1-18.7 \\
(K F 844045)\end{array}$ & NA & $\begin{array}{c}7.9 \\
\text { (KF843997) }\end{array}$ & NA & Sales et al. (2013) \\
\hline
\end{tabular}

1

2 Notes: $\mathrm{NA}=$ Not available, $\mathrm{MX}=$ Mexico. 


\section{Table 5 (on next page)}

Morphological comparison of the VRS common octopus with similar taxa. 


\begin{tabular}{|c|c|c|c|c|c|c|c|c|c|c|}
\hline \multirow{3}{*}{ Parameter } & \multicolumn{2}{|c|}{$\begin{array}{l}\text { VRS common } \\
\text { octopus }\end{array}$} & \multirow{2}{*}{\multicolumn{2}{|c|}{$\begin{array}{l}\text { O. insularis } \\
\text { Leite et al. } \\
\text { (2008); Amor } \\
\text { et al. (2016) } \\
\text { Lima et al. } \\
\text { (2017) }\end{array}$}} & \multirow{2}{*}{\multicolumn{2}{|c|}{$\begin{array}{l}\text { O. vulgaris s. s. } \\
\text { Mangold (1998); } \\
\text { Otero et al. } \\
\text { (2007); Amor et } \\
\text { al. (2016) }\end{array}$}} & \multirow{2}{*}{\multicolumn{2}{|c|}{$\begin{array}{c}\text { O. tayrona } \\
\text { Guerrero- } \\
\text { Kommritz \& } \\
\text { Camelo- } \\
\text { Guarin (2015) }\end{array}$}} & \multirow{2}{*}{\multicolumn{2}{|c|}{$\begin{array}{l}\text { O. maya } \\
\text { Voss \& Solís- } \\
\text { amírez (1966); } \\
\text { na et al. (2017) }\end{array}$}} \\
\hline & \multicolumn{2}{|c|}{ This study } & & & & & & & & \\
\hline & Min & $\operatorname{Max}$ & Min & Max & Min & $\operatorname{Max}$ & Min & $\operatorname{Max}$ & Min & Max \\
\hline Mantlle length & 101 & 189 & 80 & 190 & 80 & 350 & 24 & 130 & 48 & 210 \\
\hline Head width index & 27.67 & 50.13 & 35.00 & 48.00 & 43.58 & 61.90 & 29.20 & 104.16 & 27.00 & 48.00 \\
\hline Calamus length index & 40.79 & 58.56 & 41.00 & 56.00 & 40.39 & 67.55 & 20.00 & 50.00 & 24.00 & 27.00 \\
\hline Ligula length index & 0.92 & 1.65 & 1.30 & 1.70 & 0.66 & 1.29 & 0.42 & 1.62 & 1.40 & 1.90 \\
\hline Enlarged sucker diameter index & 8.87 & 13.75 & 9.19 & 16.00 & 16.67 & 25.60 & - & - & - & - \\
\hline Hectocotylized arm index & 229.56 & 306.88 & 188.87 & 320.44 & 320.18 & 528.85 & 96.85 & 558.30 & 216 & 348 \\
\hline Hectocotylized arm sucker count & 103 & 146 & 96 & 142 & 156 & 183 & 112 & 135 & - & - \\
\hline Funnel length index & 26.79 & 49.47 & 28.95 & 49.00 & 18.79 & 52.52 & 11.90 & 79.20 & - & - \\
\hline Mantle width index & 45.85 & 80.21 & 59.00 & 95.00 & 63.56 & 83.14 & 45.20 & 112.50 & 42.00 & 64.00 \\
\hline Web depth index & 16.35 & 24.91 & 22.00 & 29.00 & 82.09 & 146.63 & 8.90 & 82.40 & 16.00 & 30.00 \\
\hline Spermatophore length index & 28.06 & 38.68 & 27.00 & 43.00 & 31.00 & 81.00 & - & & 47.00 & 60.00 \\
\hline Gill count & & 11 & $8-$ & 11 & & 10 & & - & & \\
\hline Ocelli & & ent & Abs & sent & & sent & & sent & & \\
\hline Post-hatching lifestyle & Merol & enthic & Merob & enthic & Merok & enthic & Merol & benthic & Holo & enthic \\
\hline
\end{tabular}

3 Note: Main differences are shown in bold. 